\title{
Transportation Impact Analysis for Shipment of Irradiated N-Reactor Fuel and Associated Materials
}

\author{
P. M. Daling
}

M. S. Harris

December 1994

Prepared for the U.S. Department of Energy under Contract DE-AC06-76RLO 1830

Pacific Northwest Laboratory

Operated for the U.S. Department of Energy by Battelle Memorial Institute 


\title{
DISCLAIMER
}

This report was prepared as an account of work sponsored by an agency of the United States Government. Neither the United States Government nor any agency thereof, nor Battelle Memorial Institute, nor any of their employees, makes any warranty, expressed or implied, or assumes any legal liability or responsibility for the accuracy, completeness, or usefulness of any information, apparatus, product, or process disclosed, or represents that its use would not infringe privately owned rights. Reference herein to any specific commercial product, process, or service by trade name, trademark, manufacturer, or otherwise does not necessarily constitute or imply its endorsement, recommendation, or favoring by the United States Government or any agency thereof, or Battelle Memorial Institute. The views and opinions of authors expressed herein do not necessarily state or reflect those of the United States Government or any agency thereof.

\author{
PACIFIC NORTHWEST LABORATORY \\ operated by \\ BATTELLE MEMORIAL INSTITUTE \\ for the \\ UNITED STATES DEPARTMENT OF ENERGY \\ under Contract DE-ACO6-76RLO 1830
}

Printed in the United States of America

Available to DOE and DOE contractors from the

Office of Scientific and Technical Information, P.O. Box 62, Oak Ridge, TN 37831; prices available from (615) 576-8401. FTS 626-8401.

Available to the public from the National Technical Information Service, U.S. Department of Commerce, 5285 Port Royal Rd., Springfield, VA 22161. 


\section{DISCLAIMER}

Portions of this document may be illegible in electronic image products. Images are produced from the best available original document. 
$\frac{P N L-10249}{U C-630}$

UC -630

TRANSPORTATION IMPACT ANALYSIS

FOR SHIPMENT OF IRRADIATED

N-REACTOR FUEL AND ASSOCIATED

MATERIALS

P. M. Daling

M. S. Harris

December 1994

Prepared for

the U. S. Department of Energy

Under Contract DE-AC06-76RLO 1830

Pacific Northwest Laboratory

Richland, Washington 99352

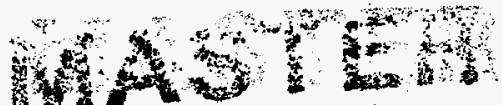




\section{EXECUTIVE SUMMARY}

An analysis of the radiological and nonradiological impacts of highway transportation of $\mathrm{N}$-Reactor irradiated fuel ( $\mathrm{N}$-fuel) and associated materials is described in this report. $\mathrm{N}$-fuel is proposed to be transported from its present locations in the 105-KE and 105-KW Basins, and possibly the PUREX Facility, to the 327 Building for characterization and testing. Each of these facilities is located on the Hanford Site, which is near Richland, Washington. The projected annual shipping quantity is $500 \mathrm{kgU} / \mathrm{yr}$ for 5 years for a total of $2500 \mathrm{kgU}$. It was assumed the irradiated fuel would be returned to the $\mathrm{K}$ Basins following characterization, so the total amount of fuel shipped was assumed to be $5000 \mathrm{kgU}$. The shipping campaign may also include the transport and characterization of liquids, gases, and sludges from the storage basins, including fuel assembly and/or canister parts that may also be present in the basins. The impacts of transporting these other materials are bounded by the impacts of transporting $5000 \mathrm{kgU}$ of $\mathrm{N}$-fuel. This report was prepared to support an environmental assessment of the $\mathrm{N}$-fuel characterization program.

The RADTRAN 4 and GENII computer codes were used to evaluate the radiological impacts of the proposed shipping campaign. RADTRAN 4 was used to calculate the routine exposures and accident risks to workers and the general public from the $\mathrm{N}$-fuel shipments. The GENII computer code was used to calculate the consequences of the maximum credible accident. The results indicate that the transportation of $\mathrm{N}$-fuel in support of the characterization program should not cause excess radiological-induced latent cancer fatalities or traffic-related nonradiological accident fatalities. The consequences of the maximum credible accident are projected to be small and result in no excess latent cancer fatalities. 



\section{CONTENTS}

EXECUTIVE SUMMARY ..................... $i$.

ACRONYMS AND ABBREVIATIONS ........... ix

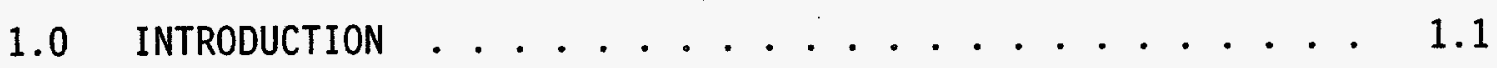

2.0 N-FUEL SHIPMENT CHARACTERISTICS ........................ 2.

2.1 SHIPPING CASK DESCRIPTION . . . . . . . . 2.1

2.2 N-REACTOR IRRADIATED FUEL DESCRIPTION . . . . 2.1

2.3 DESCRIPTION OF N-REACTOR FUEL SHIPPING CAMPAIGN . . 2.3

3.0 APPROACH TO THE CALCULATION OF TRANSPORTATION RADIOLOGICAL IMPACTS ..................... 3.1

3.1 RADTRAN 4 COMPUTER CODE DESCRIPTION . . . . . 3.1

3.2 GENII COMPUTER CODE DESCRIPTION . . . . . . . . 3.3

4.0 RESULTS OF TRANSPORTATION IMPACT ANALYSIS . . . . . . 4.1

4.1 RESULTS OF POPULATION EXPOSURE AND RISK

CALCULATIONS ........................... 4.1

4.1.1 Routine Radiological Impact Analysis . . . . 4.1

4.1.2 Impacts From Accidents Involving Radioactive
Materials . . . . . . . . . 4.3

4.2 CONSEQUENCES OF MAXIMUM CREDIBLE TRANSPORTATION ACCIDENT . . . . . . . . . . . . . . 4.9

4.2.1 Input Data for Maximum Credible Accident Analysis .............. 4.10

4.2.2 Results of Maximum Credible Accident

Analysis ............... 4.11 
4.3 NONRADIOLOGICAL TRANSPORTATION IMPACTS . . . 4.12

4.3.1 Description of the Approach to Calculating Nonradiological Impacts........ 4.13

4.3.2 Results of Nonradiological Accident Impact Calculations ............ 4.13

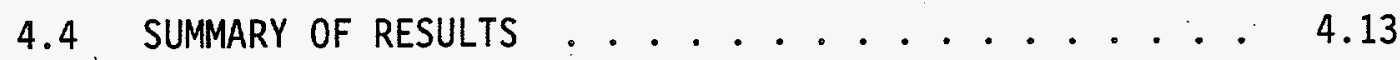

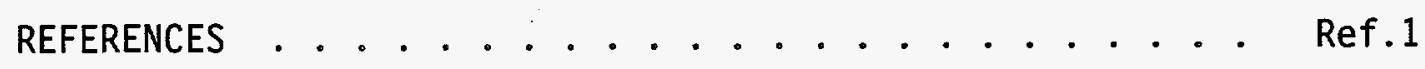

APPENDIX A - COMPUTER CODE INPUT FILES . . . . . . A.1 


\section{$\underline{\text { TABLES }}$}

Table 2.1. Radionuclide Inventories of N-Reactor Fuel Shipments. . 2.5

Table 4.1. Input Data for Analysis of Routine Transport Impacts. - 4.2

Table 4.2. Results of Normal Transportation Impact Calculations. . 4.4

Table 4.3. Conditional Probabilities of Accidents in

Six Severity Categories . . . . . . . . . . . . 4.6

Table 4.4. Release Characteristics used in RADTRAN 4 Calculations

Table 4.5. Radionuclide Release Quantities for the Maximum Credible Accident . . . ............. 4.11

Table 4.6. Consequences of Maximum Credible Accident . . . . . . 4.12

Table 4.7. Summary of Transportation Impacts for Shipment of $\mathrm{N}$-Reactor Fuel on the Hanford Site . . . . . . . 4.14

\section{FIGURES}

Figure 2.1 Illustration of Mark IV Fuel Element . . . . . . . 2.2 



\title{
ACRONYMS AND ABBREVIATIONS
}

\author{
ANSI American National Standards Institute. \\ DOE U. S. Department of Energy. \\ DOT U. S. Department of Transportation. \\ EA environmental assessment. \\ GENII Computer code used to assess the consequences of a release of \\ radioactive material to the environment. \\ HIGHWAY Computer code used to estimate travel. distances, population \\ densities, and fractions of travel in rural, suburban, and urban \\ areas between certain origin and destination facilities. \\ ICRP International Commission on Radiological Protection. \\ IEEE Institute of Electrical and Electronics Engineers. \\ kgU kilograms uranium. \\ LCF Latent cancer fatality \\ MTU metric tons uranium. \\ $\mathrm{N}$-fuel . N-Reactor irradiated fuel. \\ NRC U. S. Nuclear Regulatory Commission. \\ PNL Pacific Northwest Laboratory. \\ PUREX Plutonium and Uranium Extraction; fuel reprocessing plant at the \\ Hanford Site. \\ RADTRAN 4 Computer code used to assess radiological impacts of routine \\ transportation and accidents during transportation of radioactive \\ materials. \\ SPR Single-pass reactor. \\ WHC Westinghouse Hanford Company
}




\subsection{INTRODUCTION}

Currently 1150 MTUa of N-Reactor irradiated fuel are stored in 3666 open canisters in the 105-KE Basin and 958 MTU of N-fuel are stored in 3815 sealed canisters in the 105-KW Basin at the 100 Area of the Hanford Site in Richland, Washington. Each basin also contains a small amount of irradiated single-pass reactor (SPR) fuel (0.1 MTU in 105-KW and 0.4 MTU in 105-KE). In addition, there are 2.9 MTU of SPR and 0.5 MTU of N-Reactor fuel stored at the PUREX Plant in the 200-East Area. The condition of these fuel elements is relatively uncertain, as are their current physical and chemical characteristics. This lack of reliable data has resulted in uncertainties about how to plan for processing (e.g., wet storage, dry storage, stabilization) and disposing of these materials.

Planning is currently underway for a program to 1) sample the nuclear fuel stored in the 105-KE and 105-KW Basins and possibly the nuclear fuel presently stored in the PUREX Plant; 2) transport those fuel samples to the Postirradiation Testing Laboratory at the 327 Building in the 300 Area of the Hanford Site; 3) determine their physical and chemical characteristics; 4) develop alternative fuel conditioning processes, as necessary, for 50-year storage, either wet or dry; and 5) return the unused portions of samples to the 105-KE or 105-KW Basins. The proposed program would also include transporting and characterizing the liquids, gases, and sludges from the storage basins and may include other materials (e.g., fuel assembly and/or canister parts).

This report, prepared by the Pacific Northwest Laboratory (PNL) for the Westinghouse Hanford Company (WHC), presents estimates of the radiological impacts of transporting the $\mathrm{N}$-fuel and associated material from the 105-KE and 105-KW Basins and the PUREX Plant to the 327 Building (Section 2.0). The approaches and data that were used to calculate the impacts of the maximum credible accident are presented in Section 3.0, as well as the characteristics of the radioactive shipments that are important to calculating radiological impacts. Finally, the impacts of both incident-free (routine) transport of radioactive materials (in which the shipments reach their destinations without incident) and accident-based transport are addressed in Section 4.0. The consequences of the maximum credible accident and the nonradiological impacts are also presented in Section 4.0. The results of this study will be used to develop an environmental assessment in support of the $\mathrm{N}$-Fuel Characterization Program.

a Metric tons of uranium before irradiation (MTU). Masses of uranium after irradiation amounted to $1.143 .7 \mathrm{t}$ and $958.1 \mathrm{t}$, respectively (Bergsman 1993). 


\subsection{N-FUEL SHIPMENT CHARACTERISTICS}

The principal shipment characteristics necessary to calculate the radiological impacts of onsite transport include the type of shipping container or cask, the characteristics of the material being transported (e.g., the quantity or inventory of radioactive material within the cask), and information on the shipping (e.g., the number of shipments). These parameters are presented in this section.

\subsection{SHIPPING CASK DESCRIPTION}

The shipping cask planned for use in the $\mathrm{N}$-fuel shipments is the ChemNuclear Systems, Inc., CNS 1-13G cask, or equivalent. This cask is a certified Type $B$ shipping container that meets the requirements of the U.S. Nuclear Regulatory Commission (NRC; see 10 CFR 71) and the U.S. Department of Transportation (DOT; see 49 CFR 173), as documented in NUREG-0383, Rev. 16 (NRC 1993). The CNS 1-13G has been licensed to transport enclosed and sealed oxide and metal spent nuclear fuel elements with up to $500 \mathrm{~g}$ of Uranium-235equivalent fissile inventory. Damaged $\mathrm{N}$-fuel would be placed inside an additional vented canister to help ensure containment. The cask is also certified to transport nonfissile irradiated hardware, waste materials, byproduct materials, and special nuclear materials and, therefore, is capable of transporting the other materials that may also be present in the K-Basins. For this study, the capacity of the cask was assumed to be $40 \mathrm{kgU}$ of $\mathrm{N}$-fuel per shipment.

Packaging and transporting the $\mathrm{N}$-fuel and other materials would be conducted by the Hanford Site Operations and Engineering Contractor according to Packaging Design Criteria for the $\mathrm{N}$-Reactor/Single-Pass Reactor Fuel Characterization Shipments (Stevens 1994a) and $N$ Reactor/Single Pass Reactor Fuel Characterization Shipments Safety Evaluation for Packaging (Stevens 1994b). The cask would be transported by truck on Hanford Site roads.

\subsection{N-REACTOR IRRADIATED FUEL DESCRIPTION}

$\mathrm{N}$-fuel elements consist of two concentric tubes of uranium metal, coextruded into Zircalloy-2 cladding. There are two main types of fuel elements: 1) Mark IV and Mark $1 \mathrm{~A}$ elements. 2) The use of Mark IV elements were assumed for this analysis. Mark IV fuel elements are approximately 6.15 $\mathrm{cm}(2.42 \mathrm{in.})$ outside diameter. A variety of lengths are possible, including $44.2 \mathrm{~cm}, 58.9 \mathrm{~cm}, 62.5 \mathrm{~cm}$, and $66.3 \mathrm{~cm}(17.4 \mathrm{in.,} 23.2 \mathrm{in.,} 24.6 \mathrm{in.}$, and 26.1 in.). Figure 2.1 illustrates the Mark IV fuel element. 


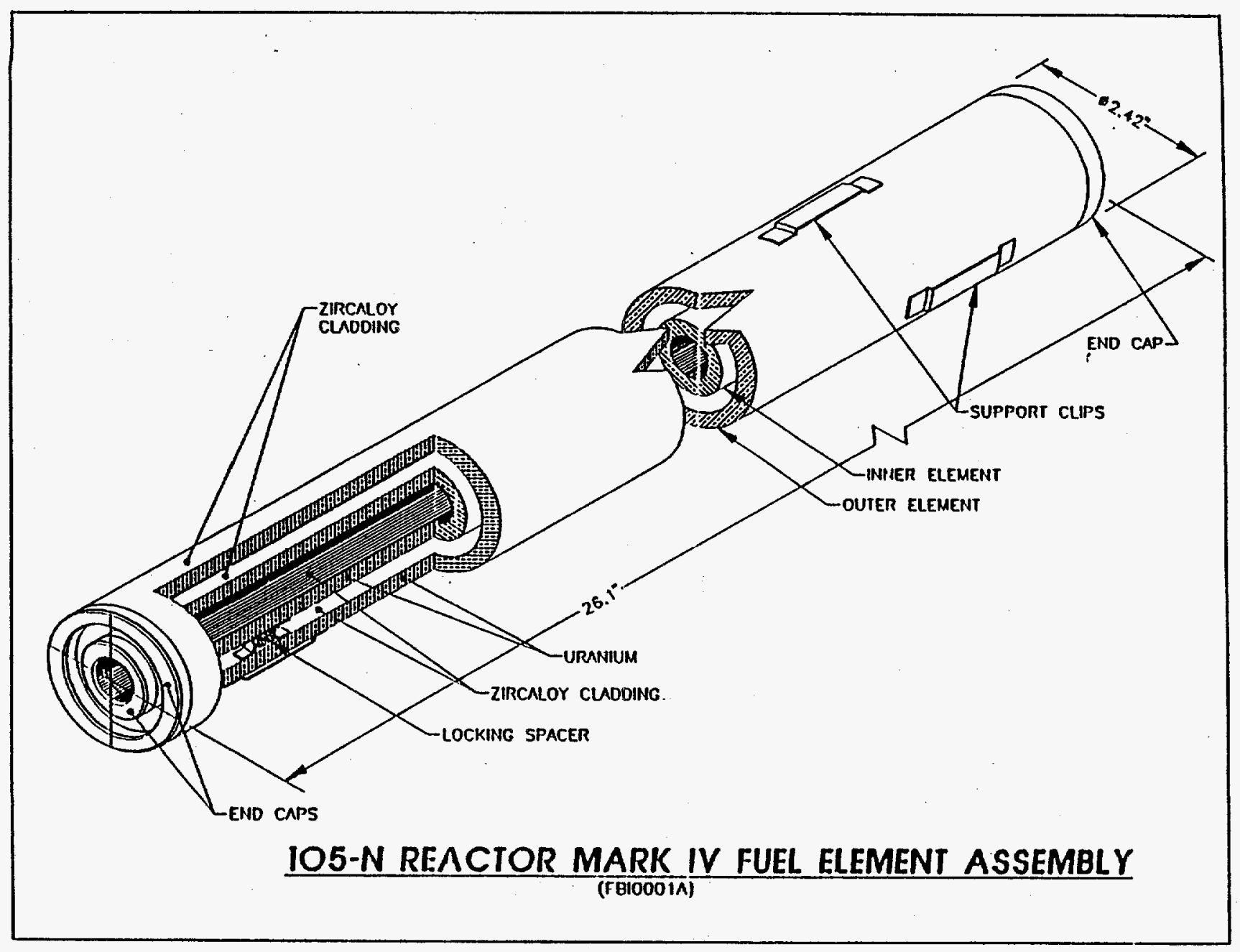

Figure 2.1. Illustration of Mark IV Fuel Element 
The fuel to be transported was assumed to have aged 10 years since it was discharged from $\mathrm{N}$-Reactor. This decay time was selected considering that approximately 85\% of the fuel was discharged between 1970 and 1980 [14 to 24 years decay time, Bergsman (1993)]. The remaining 15\% of the fuel was last irradiated, at the latest, in 1987, so it is a minimum of 7 years old. The 10-year decay time assumption was less than the weighted-average fuel age calculated using the ages and percentages given above and, therefore, was considered to be conservative.

The irradiated fuel elements to be shipped to the 327 Building include elements that have breached cladding or have otherwise been damaged. All fuel elements will have experienced some degree of corrosion and oxidation because of their relatively long-term exposure to water and/or air. Bergsman (1993) stated that a 1991 inspection of the $\mathrm{N}$-fuel in storage pools estimated that at least $12 \%$ of the fuel elements in the sample taken were damaged and that $90 \%$ of the fuel storage canisters (14 elements per canister) could contain at least one damaged fuel element. It is anticipated that the $\mathrm{N}$-fuel elements will be loaded into a canister and the fuel will be placed into the shipping cask. No credit was taken in the accident analysis for the containment capabilities provided by the canister.

\subsection{DESCRIPTION OF N-REACTOR FUEL SHIPPING CAMPAIGN}

This section provides information on the quantities of $\mathrm{N}$-fuel elements, numbers of shipments, radionuclide inventories, and assumed radiation dose rates emitted from the shipping casks. These data include the following:

- Quantity of N-Reactor fuel to be shipped. A total of $500 \mathrm{kgU}$ of $\mathrm{N}$-fuel is planned to be shipped each year for 5 years (totaling $2500 \mathrm{kgU}$ ) from the K-Basins ${ }^{a}$ in the 100 Area to the 327 Building in Hanford's 300 Area. The $2500 \mathrm{kgU}$ of $\mathrm{N}$-fuel was assumed to be returned to the K-Basins over a 5-year period after the characterization program is completed. Therefore, this assessment included the shipments to the 327 Building as well as the return shipments. Transport of samples of sludges, gases, assembly parts, etc., were assumed to be bounded by the transport of fuel and are not discussed further.

Some of the N-fuel currently at the PUREX Plant may be shipped to the 327 Building as a part of the $500 \mathrm{kgU}$ of fuel to be characterized. However, all the fuel was assumed to be shipped from the $\mathrm{K}$-basins because this maximizes the transportation impacts. 
- Number of shipments. For this study, the assumed capacity of the CNS 1$13 \mathrm{G}$ shipping cask was $40 \mathrm{kgU}$ of $\mathrm{N}$-Reactor fuel. Therefore, a total of 63 shipments of $N$-Reactor fuel would be transported to the 327 Building over a 5-year period. An additional 63 shipments would be required to return the fuel to the K-Basins. All of the shipments were assumed to be made by truck.

- Radionuclide inventories. The radionuclide inventories used in this analysis are representative of Mark IV fuel elements 10 years after reactor discharge (see Table 2.1). The basic radionuclide content of this fuel was taken from Bergsman (1993). Table 2.1 contains all of the radionuclides, including actinides, listed in Bergsman (1993).

- Radiation dose rates. Shipments were assumed to be at the regulatory maximum dose rate defined in 49 CFR 173.441. The maximum dose rates are $200 \mathrm{mrem} / \mathrm{h}$ at any point on the outer surface of the vehicle (in a closed transport vehicle only) or accessible external surface of the package, and $10 \mathrm{mrem} / \mathrm{h}$ at any point $2 \mathrm{~m}$ from the vertical planes projected by the outer lateral surfaces of the car or vehicle; or, if the load is transported in an open transport vehicle, at any point $2 \mathrm{~m}$ from the vertical planes projected from the outer edges of the vehicle.

- Transportation route. The most probable transportation route would be on Hanford roads beginning at 100-K Area, Route 1, 4-North and 4-South, and ending at the 300 Area. This route is approximately $45 \mathrm{~km}$ (28 mi.) long. Of this distance, about $15 \mathrm{~km}$ along Route 4-South from the Wye Barricade to the 300 Area, are accessible to, but are not frequented by, the general public. Since the cask is not licensed for transporting damaged fuel on public roads, Route 4 -South would be closed to public access during shipment of samples of damaged fuel assemblies or other materials, as appropriate. 
Table 2.1. Radionuclide Inventories of $\mathrm{N}$-Reactor Fuel Shipments

\begin{tabular}{|c|c|c|}
\hline Radionuclide & $\mathrm{Ci} / \mathrm{MTU}^{(\mathrm{a})}$ & $\mathrm{Ci}_{\text {/Shipment }}{ }^{(\mathrm{b})}$ \\
\hline $\begin{array}{l}\mathrm{H}-3 \\
\mathrm{Fe}-55 \\
\mathrm{Co}-60 \\
\mathrm{Kr}-85 \\
\mathrm{Sr}-90 \\
\mathrm{Y}-90 \\
\mathrm{Ru}-106 \\
\mathrm{Rh}-106 \\
\mathrm{Sb}-125 \\
\mathrm{Te}-125 \mathrm{~m} \\
\mathrm{Cs}-134 \\
\mathrm{Cs}-137 \\
\mathrm{Ba}-137 \mathrm{~m} \\
\mathrm{Ce}-144 \\
\mathrm{Pr}-144 \\
\mathrm{Pm}-147 \\
\mathrm{Sm}-151 \\
\mathrm{Eu}-154 \\
\mathrm{Eu}-155 \\
\mathrm{U}-235 \\
\mathrm{U}-238 \\
\mathrm{~Np}-237 \\
\mathrm{Pu}-238 \\
\mathrm{Pu}-239 \\
\mathrm{Pu}-240 \\
\mathrm{Pu}-241 \\
\mathrm{Am}-241 \\
\mathrm{Cm}-244\end{array}$ & $\begin{array}{l}2.64 \mathrm{E}+01 \\
7.64 \mathrm{E}+00 \\
4.92 \mathrm{E}+00 \\
4.81 \mathrm{E}+02 \\
5.53 \mathrm{E}+03 \\
5.53 \mathrm{E}+03 \\
5.15 \mathrm{E}+01 \\
5.15 \mathrm{E}+01 \\
1.27 \mathrm{E}+02 \\
3.09 \mathrm{E}+01 \\
1.22 \mathrm{E}+02 \\
7.01 \mathrm{E}+03 \\
6.64 \mathrm{E}+03 \\
2.67 \mathrm{E}+01 \\
2.67 \mathrm{E}+01 \\
1.88 \mathrm{E}+03 \\
8.74 \mathrm{E}+01 \\
8.49 \mathrm{E}+01 \\
3.42 \mathrm{E}+01 \\
1.48 \mathrm{E}-02 \\
3.26 \mathrm{E}-01 \\
2.72 \mathrm{E}-02 \\
4.82 \mathrm{E}+01 \\
1.10 \mathrm{E}+02 \\
5.77 \mathrm{E}+01 \\
4.43 \mathrm{E}+03 \\
9.26 \mathrm{E}+01 \\
4.54 \mathrm{E}+00\end{array}$ & $\begin{array}{l}1.32 \mathrm{E}+00 \\
3.82 \mathrm{E}-01 \\
2.46 \mathrm{E}-01 \\
2.41 \mathrm{E}+01 \\
2.77 \mathrm{E}+02 \\
2.77 \mathrm{E}+02 \\
2.58 \mathrm{E}+00 \\
2.58 \mathrm{E}+00 \\
6.35 \mathrm{E}+00 \\
1.55 \mathrm{E}+00 \\
6.10 \mathrm{E}+00 \\
3.51 \mathrm{E}+02 \\
3.32 \mathrm{E}+02 \\
1.34 \mathrm{E}+00 \\
1.34 \mathrm{E}+00 \\
9.40 \mathrm{E}+01 \\
4.37 \mathrm{E}+00 \\
4.25 \mathrm{E}+00 \\
1.71 \mathrm{E}+00 \\
7.40 \mathrm{E}-04 \\
1.63 \mathrm{E}-02 \\
1.36 \mathrm{E}-03 \\
2.41 \mathrm{E}+00 \\
5.50 \mathrm{E}+00 \\
2.89 \mathrm{E}+00 \\
2.22 \mathrm{E}+02 \\
4.63 \mathrm{E}+00 \\
2.27 \mathrm{E}-01\end{array}$ \\
\hline TOTAL & $3.25 E+04$ & $1.62 E+03$ \\
\hline
\end{tabular}

(a) Based on Mark IV fuel 10 years after discharge from $\mathrm{N}$-Reactor.

(b) For conservatism, these calculations are based on a capacity of $50 \mathrm{kgU}$ per shipment, although the current capacity estimate is $40 \mathrm{kgU}$ per shipment. 


\subsection{APPROACH TO THE CALCULATION OF TRANSPORTATION RADIOLOGICAL IMPACTS}

The RADTRAN 4 (Neuhauser and Kanipe 1992) and GENII (Napier et al. 1988) computer codes were used to evaluate possible radiological impacts associated with the onsite transportation of $\mathrm{N}$-fuel elements. The RADTRAN 4 program uses a combination of meteorological, demographic, health physics, transportation, packaging, and material factors to analyze risks associated with both normal transport (incident-free) and various user-selected accident scenarios. RADTRAN 4 is an update of the RADTRAN 3 (Madsen et al. 1986) and RADTRAN 2 (Taylor and Daniel 1982; Madsen et a1. 1983) computer codes. The GENII computer code was used to evaluate the radiological consequences of the maximum credible transportation accident. Brief descriptions of these computer codes are provided in the following subsections. Nonradiological risks were calculated by hand, as described in Section 4.3.

\subsection{RADTRAN 4 COMPUTER CODE DESCRIPTION}

Radiological impacts during routine transport involve doses to the public (from radiation emitted by radioactive material packages as the shipment passes by) and to transport workers (in the general vicinity of a radioactive material shipment). Even though radiation shields are incorporated into packaging designs, some radiation penetrates the package and exposes the nearby population to an extremely low dose rate. After the shipment has passed, no further exposure occurs.

Exposures to nearby populations and individuals occur as a result of the low levels of radiation emitted from the transportation packages. RADTRAN 4 calculates the doses received by many different population subgroups. For $\mathrm{N}$-fuel shipments, which would be conducted entirely on the Hanford Site and would be shipped by truck, many of the RADTRAN population groups do not apply (e.g., rail crews, flight attendants, doses to handlers, and doses at intermediate stops). No intermediate stops are anticipated enroute because of the short shipping distance so no exposures will occur at food/rest stops. The radiological impacts of incident-free transport of $\mathrm{N}$-Reactor fuel are calculated for the truck crew, persons in passing vehicles, and the population surrounding the highways.

The RADTRAN 4 program consists of seven submodels:

(1) A material model allows users to select basic material parameters, including number of curies of each isotope per package, average total photon energy per disintegration, the rate at which released material is deposited on the ground, cloudshine dose factors, the physical characteristics of the material, half-life, and measures of the radiotoxicity of the dispersed material.

(2) A transportation model considers accident rates for each transportation mode (truck, van, rail, cargo and passenger air, barge, and ship), traffic patterns (fraction of travel occurring on various road types, 
through different population zones, and under both rush-hour and normal traffic conditions), and basic shipment information (number of crewmen, handling and storage times and duration and number of stops).

(3) An accident severity and package release model classifies accidents according to severity (e.g., fire; crush, impact, and puncture forces) and defines the respirable fraction (particles less than $10 \mu \mathrm{m}$ ) of airborne material released from packages.

(4) A meteorological dispersion model describes the diffusion of a cloud of aerosolized debris released during an accident.

(5) A population distribution model describes the distribution and relative densities of people in three population zones (rural, suburban, and urban) and in certain specific areas, such as pedestrian walkways, warehouses, and air terminals.

(6) A health effects model a evaluates the radiotoxicity of materials in terms of the potential for producing acute fatalities, early morbidities, genetic effects, and latent cancer fatalities.

(7) An optional economic model evaluates the economic impacts connected with surveillance, cleanup, evacuation, and long-term, land-use denial activities.

Route-specific aggregate data were developed using the HIGHWAY computer code (Joy and Johnson 1983). The route-specific data established here included population densities and shipping distances in various population density regions.

The radiological impacts from transportation accidents were expressed according to the level of consequence, probability of occurrence, and level of risk. A risk figure-of-merit was calculated by summing the products of the probability of each specific accident and its associated level of consequence.

The following assumptions were incorporated in the RADTRAN 4 program:

- Dose calculations in the population exposure model assumed that the package or shipping cask is a point source or line source of radiation (1ine-source issused for handlers who work in close proximity to packages; point-source is used elsewhere).

This model does not incorporate BEIR $V$ or International Commission on Radiological Protection (ICRP) 60 health effects conversion factors. The authors of RADTRAN 4 recommend obtaining results as dose risks and applying BEIR $V$ or ICRP 60 health effects conversions to them. 
- Radioactive materials released from a package during an accident were assumed to be dispersed according to standard Gaussian puff-type models. However, the user may define alternative dispersion factors, if desired.

- External radiation exposures from ground contamination were calculated using an infinite plane source model.

- Sensitivity analyses were performed for several applications (e.g., incident-free transportation; vehicular accidents) of the RADTRAN III program and are documented in Neuhauser and Reardon (1986) and Madsen et al. (1986). RADTRAN 4 is in compliance with the American National Standards Institute/Institute for Electrical and Electronics Engineer's (ANSI/IEEE) standard 730-89 for software quality assurance and all benchmarking is documented in the accompanying software verification and validation plan.

\subsection{GENII COMPUTER CODE DESCRIPTION}

The GENII system (Napier et a1. 1988), also referred to as the Hanford Environmental Dosimetry Software System, was used to perform the radiation dose calculations for the maximum credible accident. Specifically, the maximum offsite individual dose and integrated population dose were calculated. A description of the GENII computer code as well as the input parameters used in the GENII calculations are presented in this section.

GENII is capable of calculating the following doses:

- doses from acute releases, including options for annual dose, committed dose, and accumulated dose

- doses from chronic releases, including options for annual dose, committed dose, and accumulated dose

- exposure pathways evaluated including those through direct exposure via water, soil, and air as well as inhalation and ingestion pathways

- acute and chronic elevated and ground-level releases to air

- acute and chronic releases to water

- initial contamination of soil or surfaces

- radionuclide decay.

The pathways considered in this analysis included inhalation, submersion, and external exposures due to ground contamination. Separate calculations were performed to quantify potential ingestion doses for the nearest offsite resident and the offsite population. GENII has been approved for use by the Hanford Environmental Dose Overview Panel (HEDOP). 
GENII is composed of seven linked computer codes and their associated data libraries. The seven programs may be divided into three categories: user interfaces (interactive, menu-driven programs to assist the user); internal and external dose factor generators; and the environmental dosimetry programs. For more information, the reader is referred to Napier et a1. (1988). Inputs to GENII that were used in the analysis of onsite and offsite doses from this accident are discussed in Section 4.0. 


\subsection{RESULTS OF TRANSPORTATION IMPACT ANALYSIS}

This chapter describes the input parameters and results of the transportation impact analysis for shipment of irradiated N-Reactor fuels. Separate subsections are provided for the population radiological exposure and àccident risk calculations (RADTRAN 4 results), maximum credible accident consequences (GENII results), and nonradiological accident risks.

\subsection{RESULTS OF POPULATION EXPOSURE AND RISK CALCULATIONS}

This subsection presents the results of the RADTRAN 4 analysis of the proposed irradiated $\mathrm{N}$-fuel shipments. Section 4.1 .1 presents the routine or incident-free exposures, and Section 4.1 .2 presents the accident risk assessment results. Each subsection also specifies the important RADTRAN 4 input parameters that were used in this analysis. A complete RADTRAN 4 input listing is provided in Appendix A.

\subsubsection{Routine Radiological Impact Analysis}

This section describes the incident-free or routine radiological impact analysis performed in support of this assessment. Incident-free transport refers to the situation in which the shipments of radioactive materials reach their destinations without releasing the package contents. Impacts from accidents are discussed later. The following subsections describe the approach, discuss the input data and assumptions, and present the results.

\subsubsection{Input Data for Routine Highway Transportation Impacts}

The miscellaneous input data used in the analysis of routine radiation dose impacts during highway transport of $\mathrm{N}$-fuel elements are listed in Table 4.1. These data are RADTRAN 4 default values, except where indicated, and are self-explanatory.

The population densities of the regions across which shipments must travel will influence the transportation impacts. Route-specific data for the Hanford roadway route between the 100 Area and 300 Area were estimated from the HIGHWAY computer model (Joy and Johnson 1983). The population data are Hanford Site-specific. Traffic counts used in the analysis are RADTRAN default values; they do not account for peaks that arise from rush-hour traffic. However, the $\mathrm{N}$-Reactor fuel shipments are not expected to be made during rush hour, so peak traffic density data are not relevant. Furthermore, because the shipments are short, no stops for food, rest, or refueling were assumed. The route data are summarized in Table 4.1. 
Table 4.1. Input Data for Analysis of Routine Transport Impacts(a)

\begin{tabular}{|c|c|}
\hline RADTRAN 4 Parameter & Value \\
\hline Fraction of travel in rural zone $\mathrm{b}^{(b)}$ & 97.1 \\
\hline $\begin{array}{l}\text { Fraction of travel in suburban } \\
\text { zone }^{(b)}\end{array}$ & 2.9 \\
\hline Fraction of travel in urban zone $e^{(b)}$ & 0.0 \\
\hline $\begin{array}{l}\text { Radiation dose rate at } 1 \mathrm{~m} \text { from } \\
\text { cask, } \mathrm{mrem} / \mathrm{h}^{(c)}\end{array}$ & 14 \\
\hline Number of crewmen & 2 \\
\hline Distance from source to crew, $\mathrm{m}$ & 10 \\
\hline Number of people per vehicle & 2 \\
\hline $\begin{array}{l}\text { Traffic count in rural zone, one- } \\
\text { way vehicles/h }\end{array}$ & 470 \\
\hline $\begin{array}{l}\text { Traffic count in suburban zone, } \\
\text { one-way vehicles/h }\end{array}$ & 780 \\
\hline $\begin{array}{l}\text { Traffic count in urban zone, one- } \\
\text { way vehicles/h (Information onty; } \\
\text { no travel in urban areas) }\end{array}$ & 2800 \\
\hline One-way shipping distance, $\mathrm{km}^{(b)}$ & 45.1 \\
\hline $\begin{array}{l}\text { Rural population density, } \\
\text { people/ } / \mathrm{km}^{2}(\mathrm{~b})\end{array}$ & 2.4 \\
\hline $\begin{array}{l}\text { Suburban population density, } \\
\text { people } / \mathrm{km}^{2}(b)\end{array}$ & 89.8 \\
\hline $\begin{array}{l}\text { Urban population density, } \\
\text { people } / \mathrm{km}^{2}(\mathrm{~b})\end{array}$ & 0.0 \\
\hline
\end{tabular}

(a) Values are default values taken from and Neuhauser and Kanipe (1992), except where otherwise indicated.

(b) Source: HIGHWAY computer code calculations performed for this study.

(c) RADTRAN 4 will internally set the dose-rate to the regulatory maximum value when this dose rate is specified. 
Radiation dose rates emitted from the shipping cask were assumed to be equivalent to the regulatory limits given in 49 CFR 173 (maximum surface dose rate of $200 \mathrm{mrem} / \mathrm{h}$ and maximum of $10 \mathrm{mrem} / \mathrm{h}$ at $2 \mathrm{~m}$ from the surface of the cask). This assumption contributed to the conservatism of the analysis because the shipment dose rates cannot be larger than this value and most likely will be substantially smaller. No credit was taken for shielding and for the exclusion of personnel from the surface of the cask that is provided by external devices such as personnel barriers or impact limiters.

\subsubsection{Results of Routine Radiological Impact Calculations}

The RADTRAN 4 computer code was applied to calculate the routine radiation doses to transport workers and the public that are estimated to result from transporting of $\mathrm{N}$-fuel to and from the 327 Building. The results of the normal transportation impact calculations are presented in Table 4.2. As shown, the total dose to truck crewmembers (workers) amounts to about 0.08 person-rem for all of the shipments. Total public doses were calculated to be about 0.03 person-rem. Health effects were estimated as the probability of a latent cancer fatality based on the recommendations of the International Commission on Radiological Protection in its Publication 60 (ICRP 1991). There were no excess latent cancer fatalities predicted to result from routine exposures to the $\mathrm{N}$-Reactor fuel shipments.

\subsubsection{Impacts From Accidents Involving Radioactive Materials}

Radiological accident impacts are addressed in this report as integrated population risks (i.e., accident frequencies times consequences integrated over the entire shipping campaign), as well as the consequences of the maximum credible accident. Population risk calculations were performed using the RADTRAN 4 computer code (Neuhauser and Kanipe 1992). This section presents descriptions of the analyses performed using this computer code. Descriptions of the maximum credible accident analyses are provided in Section 4.2.

For this analysis, risk was defined as the product of the probability of occurrence of an accident involving the $\mathrm{N}$-Reactor fuel shipments and the consequences of an accident. Consequences were expressed in terms of the radiological exposures and latent cancer fatalities resulting from a release of radioactive material from the packaging or the exposure of persons to radiation that could result from damaged package shielding. The probability of an accident that involves radioactive materials was expressed in terms of the expected number of accidents per unit distance integrated over the total distance traveled. The response of the shipping cask and N-Rector fuel to the accident environment and, hence, the probability of release or loss of shielding, is related to the severity of the accident.

The probabilities of transportation accident occurrences that would release significant quantities of radioactive material are small because the shipping casks are designed to withstand severe transportation accident conditions. Accidents on the road are difficult to totally eliminate. 
Table 4.2. Results of Normal Transportation Impact Calculations

\begin{tabular}{|c|c|c|}
\hline Population Group & $\begin{array}{c}\text { Radiological Dose, } \\
\text { person-rem }\end{array}$ & $\begin{array}{c}\text { Latent Cancer } \\
\text { Fatalities }\end{array}$ \\
\hline Worker & $7.5 \mathrm{E}-02$ & None (3.0E-05) \\
\hline Public & $3.2 \mathrm{E}-02$ & None (1.6E-05) \\
\hline Total & $1.1 \mathrm{E}-01$ & None (4.6E-05) \\
\hline
\end{tabular}

(a) The health effect conversion factors used in this study were 5E-04 LCF/person-rem for public exposures and 4E-04 LCF/person-rem for worker exposures (ICRP 1991).

(b) This population group included persons in passing vehicles. Since the shipments would be completed entirely within the Hanford Site's boundaries, this dose would be received primarily by Hanford workers. However, since part of the route would include public roads, these doses were assigned to the public group.

However, because the shipping casks are capable of withstanding severe transportation accident environments, including severe mechanical and thermal environments, only a small fraction of the accidents involve conditions that would be severe enough to result in a release of radioactive material. Accidents with severities exceeding design standards for shipping packages (see 10 CFR 71 and 49 CFR 173) could potentially occur, but their probability is extremely smal1. According to Fischer et al. (1987), approximately $99.4 \%$ of all truck accidents and $98.7 \%$ of a 11 rail accidents are less severe than the hypothetical test conditions given in 10 CFR 71 . Thus, there is only a slight possibility that an accident could occur accompanied by a release or loss of package shielding.

Should an accident involving an $\mathrm{N}$-Reactor fuel shipment occur, a release of radioactive material could occur only if the shipping cask and fuel elements were to become breached. Failed fuel elements are also being shipped; however, all the fuel elements would be packaged into canisters before they are placed in the shipping cask. The canister would provide an additional barrier to a release of radioactive materials from the fuel elements. A breach would most likely be a small gap in a seal or small split in the cask or cladding. For the radioactive material to reach the environment, it would have to become released from the fuel matrix, pass through the breach in the fuel element cladding, and then pass through the breach in the cask. Materials released from the cask, including the small particles or vapors, would in turn become dispersed and diluted by weather action and a fraction would be deposited on the ground (i.e., drop out of the contaminated plume) in the surrounding region. Emergency response crews arriving on the scene would evacuate and secure the area to exclude bystanders from the accident scene. The released material would then be cleaned up using 
standard decontamination techniques, such as excavation and removal of contaminated soil. Monitoring of the area would be performed to locate contaminated areas and to guide cleanup crews in their choice of protective clothing and equipment (e.g., fresh-air equipment, filter masks.). Access to the area would be restricted by Federal and/or state radiation control agencies until it had been decontaminated to safe levels.

The RADTRAN 4 computer code was used to calculate the radiological risk of transportation accidents involving N-Reactor fuel shipments. The RADTRAN 4 methodology was summarized previously. For further details, refer to the discussions presented by Madsen et al. (1986) and Neuhauser and Kanipe (1992).

\subsubsection{Input Data for the Analysis of Transportation Accident Risks}

There are five major categories of input data needed to calculate transportation risk impacts using the RADTRAN 4 computer code. These are 1) accident probability, 2) release quantities, 3) atmospheric dispersion parameters, 4) population distribution parameters, and 5) human uptake and dosimetry models. Each of these major areas is discussed below.

\section{Accident Probability}

The probability of a severe accident is calculated by multiplying an overall accident rate (accidents per truck-mile) by the conditional probability that an accident will involve mechanical and/or thermal conditions that are severe enough to result in cask failure and subsequent release of radioactive material. For this analysis, six accident severity categories were defined, with category 1 as the least severe and category 6 as the most severe. The conditional probabilities of encountering accident conditions in each severity category were taken from a U.S. Department of Energy document (DOE 1.994), which were developed using a binning process based on the conditional probabilities given by Fischer et a1. (1987). These conditional probabilities are shown in Table 4.3. The overall accident rates were taken from DOE (1994) and amount to 2.5E-07, 1.61E-07, and $1.61 \mathrm{E}-07$ accidents $/ \mathrm{km}$ in rural, suburban, and urban population zones, respectively. These data were derived from state-level traffic accident statistics and are representative of accident rates in the State of Washington.

\section{Release Fractions for $\mathrm{N}$-Reactor Fuel Shipments}

Release fractions (array RFRAC in RADTRAN 4) are used to determine the quantity of radioactive material released to the environment from severe accidents. The quantity of material released is a function of the severity of the accident (i.e., thermal and mechanical conditions produced in the accident), the response of the shipping cask and fuel elements to these conditions, and the physical and chemical properties of the material being shipped. The basis for the release fractions used in this analysis are discussed below. 
Table 4.3. Conditional Probabilities of Accidents in Six Severity Categories

\begin{tabular}{|c|c|c|c|c|c|c|}
\hline \multirow{2}{*}{$\begin{array}{l}\text { Conditional Probability } \\
\text { (i.e., given the prior } \\
\text { occurrence of an } \\
\text { accident) }\end{array}$} & \multicolumn{6}{|c|}{ Severity Category } \\
\hline & 1 & 2 & 3 & 4. & 5 & 6 \\
\hline $\begin{array}{l}\text { Rural, Suburban, and } \\
\text { Urban Zones }\end{array}$ & 0.9943 & $4.05 E-05$ & $3.82 \mathrm{E}-03$ & $1.55 \mathrm{E}-05$ & $1.80 \mathrm{E}-03$ & $9.84 E-06$ \\
\hline
\end{tabular}

A set of six-parameter arrays was established to describe the release fractions. Release fractions were assigned to each accident severity category for each type of material in the shipment (e.g., gases, particulates). The first set of release fractions related to the releases expected from the normal and hypothetical accident conditions of transport that are defined in 10 CFR 71. Because the cask is a certified Type B packaging, the cask could withstand the 10 CFR 71 hypothetical conditions without loss of contents. Consequently, the release fraction for severity category 1 for all material types was set equal to zero.

The release fractions for the remaining severity categories were taken directly from the Draft Environmental Impact Statement (EIS) on the DOE Spent Nuclear Fuel Management Program (DOE 1994, Appendix I). This EIS derived release fractions based on laboratory measurements of release fractions from aluminum fuels at high temperatures (Shibata et al. 1984). Data in Fischer et al. (1987) were also used. The EIS concluded that the aluminum fuel release fractions bounded the release fractions for other metallic fuels, including $\mathrm{N}-$ Reactor fuel, primarily because of the lower melting point of aluminum relative to uranium metal. The release fractions used in this analysis are shown in Table 4.4. For an additional conservatism, $100 \%$ of the released material was assumed to be dispersible, and $100 \%$ of the dispersed material was assumed to be in the form of respirable particles. These assumptions are very conservative. The suggested value for the fraction of released particulate materials that are respirable is 5\% (Wilmot 1981). Release fractions from the cask cavity to the environment for volatile materials (e.g., cesium and iodine) may also be $5 \%$ of the material released from the fuel element (Wilmot 1981). Therefore, because of these conservative assumptions, it is believed that the results bound the impacts of accidents involving $\mathrm{N}$-fuel shipments and minimize the effects of uncertainties in the release fractions presented in Table 4.4.

\section{Atmospheric Dispersion Parameters}

The RADTRAN 4 computer code offers a default set of atmospheric dispersion data that may be used in the consequence calculations. These atmospheric dispersion parameters have been used in many previous environmental documents. For consistency with past studies, the default atmospheric dispersion data offered in RADTRAN 4 were used in this assessment. 
Table 4.4. Release Characteristics used in RADTRAN 4 Calculations

\begin{tabular}{|c|c|c|c|c|c|c|}
\hline \multirow[b]{2}{*}{ Array } & \multicolumn{6}{|c|}{ Accident Severity Category } \\
\hline & 1 & 2 & 3 & 4 & 5 & 6 \\
\hline \multicolumn{7}{|l|}{$\begin{array}{l}\text { RFRAC (Release } \\
\text { fraction) }\end{array}$} \\
\hline $\begin{array}{ll}\text { 1. } & \text { Gases } \\
\text { 2. } & \text { Cesium } \\
\text { 3. } & \text { Ruthenium } \\
\text { 4. } & \text { Particles }\end{array}$ & $\begin{array}{l}0.0 \\
0.0 \\
0.0 \\
0.0\end{array}$ & $\begin{array}{l}9.9 \mathrm{E}-03 \\
3.0 \mathrm{E}-08 \\
4.1 \mathrm{E}-09 \\
3.0 \mathrm{E}-10\end{array}$ & $\begin{array}{l}3.3 \mathrm{E}-02 \\
1.0 \mathrm{E}-07 \\
1.4 \mathrm{E}-08 \\
1.0 \mathrm{E}-09\end{array}$ & $\begin{array}{l}3.9 \mathrm{E}-01 \\
1.0 \mathrm{E}-06 \\
2.4 \mathrm{E}-07 \\
1.0 \mathrm{E}-08\end{array}$ & $\begin{array}{l}3.3 \mathrm{E}-01 \\
1.0 \mathrm{E}-06 \\
1.4 \mathrm{E}-07 \\
1.0 \mathrm{E}-08\end{array}$ & $\begin{array}{l}\text { 6. } 3 \mathrm{E}-01 \\
1.0 \mathrm{E}-05 \\
2.0 \mathrm{E}-06 \\
1.0 \mathrm{E}-07\end{array}$ \\
\hline $\begin{array}{l}\text { AEROSOL (fraction } \\
\text { of released } \\
\text { material that is in } \\
\text { dispersible form) }\end{array}$ & 0.0 & 1.0 & 1.0 & 1.0 & 1.0 & 1.0 \\
\hline $\begin{array}{l}\text { RESP (fraction of } \\
\text { dispersed material } \\
\text { that in respirable } \\
\text { form) }\end{array}$ & 0.0 & 1.0 & 1.0 & 1.0 & 1.0 & 1.0 \\
\hline
\end{tabular}

(a) These arrays were used for releases of all four material types (gases, cesium, ruthenium, and particulates) listed above.

\section{Population Distribution Parameters}

Population distribution data used by RADTRAN 4 include population densities in rural, suburban, and urban zones as well as the fractions of travel in each zone. These input parameters were developed on a routespecific basis using the HIGHWAY computer program (Joy and Johnson 1983). The population distributions used in this analysis were shown previously in Table 4.1.

Human Uptake of Radionuclides and Dosimetry Models

The dosimetry system incorporated into the RADTRAN 4 code is summarized below:

- Radionuclide half-lives and photon energies were taken from the International Commission on Radiological Protection's Radionuclide Transformations, Energy, and Intensity of Emissions (ICRP 1983).

- Cloud dose factors or the effective factor for immersion in air contaminated with specified radionuclides were taken from DOE (1988a). 
- Committed effective dose equivalent conversion factors for 50-year committed doses from inhalation were taken from Dunning (1983) and DOE $(1988 b)$.

- Ingestion doses were not calculated in this assessment.

Additional information on the dose conversion factors used in RADTRAN 4 is available in Neuhauser and Kanipe (1992). The complete RADTRAN 4 input file listing is provided in Appendix $A$.

The RADTRAN 4 computer code was applied to calculate population doses (person-rem) from accidents. This allows the user to convert the population doses to health effects using the most recent health effect conversion factors from ICRP-60 (ICRP 1991). The health effect conversion factors used in this assessment were shown in Table 4.2.

\subsubsection{Results of Transportation Accident Risk Analysis}

The RADTRAN 4 computer code was used to calculate the impacts of transportation accidents involving the $\mathrm{N}$-Reactor fuel shipments. As explained previously, the impacts are presented in terms of the probabilisticallyweighted consequences, or risks, of transportation accidents. Risk impacts are the product of the probability and the consequences of transportation accidents. Risk impacts have been integrated over all of the shipments.

The total probabilistically-weighted impacts of transportation accidents involving the $126 \mathrm{~N}$-Reactor fuel shipments were calculated to be about 2E-08 person-rem. No excess fatalities are predicted to result from this action. The dominant contributors to these impacts were determined to be potential releases of Strontium-90, Cesium-137, Plutonium-238, P1utonium-239, Plutonium-240, Plutonium-241, and Americium-241. The dominant exposure pathways were inhalation and resuspension.

\subsection{CONSEQUENCES OF MAXIMUM CREDIBLE TRANSPORTATION ACCIDENT}

This section presents the input parameters and results of the maximum credible accident consequence analysis. The GENII computer code was used for these calculations. Results are presented in terms of the population dose in the region surrounding the Hanford Site, as well as the doses to the maximum exposed offsite individual and collocated workers.

Radiation doses were calculated for various potential receptors as the effective dose equivalent. Standard assumptions for the Hanford Site were used as described by Schreckhise et al. (1993). The potential receptors are described below: 
- Collocated worker: This receptor was defined is a worker who was onsite but outside the 327 Building $^{\text {a }}$ where the accident was assumed to occur. This person was assumed to be located $100 \mathrm{~m}$ east-southeast (ESE) of the accident location. An exposure duration of 2 hours was assumed, corresponding to a reasonable maximum time to evacuate the Hanford Site in the event of an accident. Internal exposure via inhalation and external exposures via submersion and groundshine pathways were considered.

- Offsite resident: This receptor was defined as the nearest permanent offsite resident to the assumed accident location. This person was assumed to be located about $1400 \mathrm{~m}$ east-southeast of the 327 Building and was exposed for the entire duration of the release. Two cases were evaluated; one case considered exposures via inhalation, submersion, and groundshine and the second case involved exposures via the ingestion of contaminated food and treated drinking water pathways.

- Onsite - public: This receptor was assumed to a member of the public who was temporarily at the nearest public access location to the accident site. For the assumed accident location used in this analysis, this person was located approximately $600 \mathrm{~m}$ ESE of the 327 Building. As with the collocated worker, this person was assumed to be exposed to the release for 2 hours and the pathways considered were inhalation, submersion, and groundshine.

- Offsite population: Collective doses to the population within $80 \mathrm{~km}$ (50 mi) of the Hanford Site were calculated. The population was assumed to be exposed for the entire duration of the accidental release. Two cases were considered, as discussed above, for offsite residents (i.e., one case involving inhalation, submersion, and groundshine pathways and a second case involving the ingestion pathway only).

The input data and results of the GENII calculations are discussed in the following subsections. Complete input file listings for the GENII computer runs are provided in Appendix $A$.

The 327 Building was selected for the accident location because it is the facility that is closest to the Hanford Site boundary and to the nearest resident. This tends to maximize the public doses and has little effect on the worker doses.

Ingestion doses are reported separately because protective action guidelines specify mitigative measures to prevent consumption of contaminated food. 


\subsubsection{Input Data for Maximum Credible Accident Analysis}

The GENII computer code requires the user to input the receptor location as well as the weather data applicable to the site being analyzed. The weather data used in this analysis were based on Hanford Site-specific parameters (Schreckhise et a1.1993). Joint-frequency data for the 300 Area, assuming a $10 \mathrm{~m}$ release height, were used. No credit was taken for plume meander; building wake models were not used.

The population dose resulting from the maximum credible accident was calculated using the population distribution within $80 \mathrm{~km}$ of the Hanford 300 Area. These data are given in Table G.2.3 of Schreckhise et al. (1993). To maximize the population dose, the impacts were calculated for the sector containing the highest population (i.e., in the south-southeast direction from the 300 Area).

The maximum individual and population doses were calculated assuming that the transportation accident occurs in the 300 Area. Acute ground-level release dispersion factors $(E / Q)$ for the maximum individuals were calculated using GENII. In addition, the 95th percentile E/Q values for the individuals and the population-weighted E/Q for the population dose calculations were calculated by GENII. The results are as follows: collocated worker - 7.4E-02 $\mathrm{s} / \mathrm{m}^{3}$; onsite-public - $3.5 \mathrm{E}-03 \mathrm{~s} / \mathrm{m}^{3} ;$ offsite resident $-8.7 \mathrm{E}-04 \mathrm{~s} / \mathrm{m}^{3}$; and population - 5.6E-01 person-s/m .

The following standard GENII data libraries were used in the radiological dose calculations:

- GENII version 1.485 (December 3, 1990)

- GENII Default Parameter Values (March 28, 1990 RAP)

- Radionuclide Master Library (November 28, 1990 RAP)

- External Dose Factors for GENII in person Sv/yr per Bq/n (May 8, $1990 \mathrm{R}$ )

- Internal Dose Increments, PNL Solubility Choices Rerun (December 3, 1990 PDR)

- Population within $80 \mathrm{~km}$ of the Hanford 300 Area, 1990 Census (Beck et a1. 1991)

- Joint Frequency Data: 300 Area, $10 \mathrm{~m}$, Pasquil1 A-G (1983-1991 Average).

Input parameters to the GENII calculations also included the radioactive material release quantities. For consistency with the population risk calculations, the inventories and release fractions discussed previously were used in the maximum individual dose calculations. It was determined that the frequency of a severity category 3 accident was about $6 \mathrm{E}-07 / \mathrm{yr}$ (assuming that $500 \mathrm{kgU} / \mathrm{yr}$ are shipped per year) and that the frequencies of the more severe 
release categories are much smaller (less than $1 \mathrm{E}-08 / \mathrm{yr}$ ). Therefore, the maximum credible accident was concluded to be a severity category 3 event. The total quantities of each radionuclide released in this accident severity category were calculated by multiplying the per-shipment inventories in Table 2.1 by the release fractions for severity category 3 given in Table 4.4. The resulting release quantities are given in Table 4.5.

Table 4.5. Radionuclide Release Quantities for the Maximum Credible Accident

\begin{tabular}{||c|c||}
\hline $\begin{array}{c}\text { Radio- } \\
\text { nuclide }\end{array}$ & $\begin{array}{c}\text { Release } \\
\text { Quantity, } \\
\text { Ci }\end{array}$ \\
\hline $\mathrm{H}-3$ & $4.4 \mathrm{E}-02$ \\
$\mathrm{Fe}-55$ & $3.8 \mathrm{E}-10$ \\
$\mathrm{C}-60$ & $2.5 \mathrm{E}-10$ \\
$\mathrm{Kr}-85$ & $7.9 \mathrm{E}-01$ \\
$\mathrm{Sr}-90$ & $2.8 \mathrm{E}-07$ \\
$\mathrm{Ru}-106$ & $3.6 \mathrm{E}-08$ \\
$\mathrm{Te}-125 \mathrm{~m}$ & $1.5 \mathrm{E}-09$ \\
$\mathrm{Cs}-134$ & $6.1 \mathrm{E}-07$ \\
$\mathrm{Cs}-137$ & $3.5 \mathrm{E}-05$ \\
$\mathrm{Ce}-144$ & $1.3 \mathrm{E}-09$ \\
$\mathrm{Pr}-144$ & $1.3 \mathrm{E}-09$ \\
$\mathrm{Pm}-147$ & $9.4 \mathrm{E}-08$ \\
$\mathrm{Sm}-151$ & $4.4 \mathrm{E}-09$ \\
$\mathrm{Eu}-154$ & $4.2 \mathrm{E}-09$ \\
$\mathrm{U}-235$ & $7.4 \mathrm{E}-13$ \\
$\mathrm{U}-238$ & $1.6 \mathrm{E}-11$ \\
$\mathrm{~Np}-237$ & $1.4 \mathrm{E}-12$ \\
$\mathrm{Pu}-238$ & $2.4 \mathrm{E}-09$ \\
$\mathrm{Pu}-239$ & $5.5 \mathrm{E}-09$ \\
$\mathrm{Pu}-240$ & $2.9 \mathrm{E}-09$ \\
$\mathrm{Pu}-241$ & $2.2 \mathrm{E}-07$ \\
$\mathrm{Am}-241$ & $4.6 \mathrm{E}-09$ \\
$\mathrm{Cm}-244$ & $2.3 \mathrm{E}-10$ \\
\hline
\end{tabular}

\subsubsection{Results of Maximum Credible Accident Analysis}

The results of the maximum credible accident analysis are presented in Table 4.6. As shown, the population dose from the maximum credible accident (frequency approximately $1 \mathrm{E}-06 / \mathrm{yr}$ ) was calculated to be about $2.4 \mathrm{E}-03$ personrem. Applying the public health effects conversion factor shown previously in Table 4.2 results in no latent cancer fatalities (1E-06) from this accident. Collocated worker doses were calculated to be about 2.8E-04 rem. The maximum probability that this individual contracts a fatal cancer from this exposure is about $1 \mathrm{E}-07$, so no excess latent cancer fatalities in collocated workers 
are projected to result from this accident. The maximum individual dose to an offsite resident from this accident was calculated to be 3.5E-06 rem (maximum probability of a latent cancer fatality equals 2E-09) and the dose to the onsite-public receptor was calculated to be about 1.3E-05 rem (maximum probability of a latent cancer fatality equals 7E-09). Ingestion pathway doses for the offsite resident and population also indicated no excess latent cancer fatalities are anticipated.

Table 4.6. Consequences of Maximum Credible Accident

\begin{tabular}{|c|c|c|}
\hline Receptor & Dose (Rem) & $\begin{array}{l}\text { Health Effects } \\
(L C F)^{(a)}\end{array}$ \\
\hline Collocated Worker & $2.8 \mathrm{E}-04$ & None $(1 E-07)$ \\
\hline Onsite - Public & $1.3 E-05$ & None $(7 \mathrm{E}-09)$ \\
\hline $\begin{array}{l}\text { Offsite Resident } \\
\text { - Inhalation, submersion, } \\
\text { groundshine } \\
\text { - Ingestion pathway on } 7 y^{(b)}\end{array}$ & $\begin{array}{l}3.5 E-06 \\
2.8 E-04\end{array}$ & $\begin{array}{l}\text { None }(2 E-09) \\
\text { None }(1 E-07)\end{array}$ \\
\hline $\begin{array}{l}\text { Offsite Population (person-rem) } \\
\text { - Inhalation, submersion, } \\
\text { groundshine } \\
\text { - Ingestion pathway onl } y^{(b)}\end{array}$ & $\begin{array}{l}2.4 \mathrm{E}-03 \\
1.3 \mathrm{E}-01\end{array}$ & $\begin{array}{l}\text { None }(1 E-06) \\
\text { None }(7 E-05)\end{array}$ \\
\hline
\end{tabular}

(a) $\quad$ LCFs = latent cancer fatalities. Health effects are given as the maximum probability of contracting a fatal cancer.

(b) Ingestion pathway consequences are given for the season in which the consequences are largest, namely autumn.

The dominant radionuclides differed between receptors and pathways. The dominant radionuclide for the non-ingestion cases was Hydrogen-3. The dominant pathway was found to be inhalation. For the ingestion pathway doses, the dominant radionuclide was found to be Cesium-137.

\subsection{NONRADIOLOGICAL TRANSPORTATION IMPACTS}

Nonradiological impacts consist of injuries and fatalities that may result from traffic accidents as well as health effects from pollutants emitted from vehicles involved in onsite shipments of $\mathrm{N}$-Reactor fuel. These risks are in no way related to the radioactive nature of the irradiated fuel elements being transported. In fact, the nonradiological impacts would be the same even if the cargo were not radioactive materials. Health effects from routine transport (i.e., from air pollutants), are not quantified here because they are applicable only in urban areas (Ra et al. 1982) and Hanford is not an urban site. The remainder of this section focuses on the nonradiological impacts of accidents that may occur during onsite transport of $\mathrm{N}$-Reactor fuel. 


\subsubsection{Description of the Approach to Calculating Nonradiological Impacts}

The potential for accidents involving onsite shipments of $\mathrm{N}$-reactor fuel is assumed to be comparable to that of general truck transport in the United States. Rao et al. (1982) used statistics compiled by the Department of Transportation to develop non radiological risk factors. These risk factors, in units of fatalities- and injuries-per-km of travel, are multiplied by the total distance traveled by the $\mathrm{N}$-Reactor fuel shipments to calculate the expected number of nonradiological injuries and fatalities due to onsite transportation of spent nuclear fuel. These risk factors were taken from Cashwell et al. (1986) and amount to the following:

- Fatalities: 1.5E-08 fatalities/ $\mathrm{km}$ for workers (truck crew) and 5.3E-08 fatalities $/ \mathrm{km}$ for the general public.

- Injuries: $2.8 \mathrm{E}-08$ injuries $/ \mathrm{km}$ for workers and 8.0E-07 injuries $/ \mathrm{km}$ for the general public.

These unit risk factors are representative of rural areas because the Hanford Site is rural and the fatality and injury rates are higher in rural areas than urban and suburban areas. The rates given above were multiplied by the total $\mathrm{N}$-reactor shipment mileage. Total shipment-miles were determined by multiplying the total number of shipments (26) by the round-trip shipping distance between the origin and destination facilities $(90 \mathrm{~km})$.

\subsubsection{Results of Nonradiological Accident Impact Calculations}

The results of the nonradiological impact calculations for workers indicate there are no predicted fatalities and no injuries (8.5E-05 fatalities and 1.6E-04 injuries). For the general public, no fatalities or injuries are predicted (3.0E-04 fatalities and 4.5E-03 injuries). Consequently, no excess fatalities or injuries are predicted to result from nonradiological accidents involving the $\mathrm{N}$-Reactor fuel shipments. As before, these impacts would most likely be received by Hanford workers. However, because part of the route travels over public highways, the impacts to persons on the road along with the $\mathrm{N}$-Reactor fuel shipments were assigned to the general public category.

\subsection{SUMMARY OF RESULTS}

A summary of the results of this analysis is presented in this section. The results of the transportation impact calculations are presented in Table 4.7. As shown, the nonradiological impacts are significantly larger than radiological impacts. Radiological routine exposures are significantly larger than radiological accident risks. There were no excess latent cancer fatalities projected to result from the maximum credible accident, which was assumed to occur near the 327 Building. 
Table 4.7. Summary of Transportation Impacts for Shipment of $\mathrm{N}$-Reactor Fuel on the Hanford Site

\begin{tabular}{|c|c|c|}
\hline \multirow{2}{*}{ Type of Impact } & \multicolumn{2}{|c|}{ Population Group } \\
\hline & Worker & Public \\
\hline $\begin{array}{l}\text { Radiological - } \\
\text { Routine } \\
\text { Exposures, } \\
\text { LCFs }^{(a)}\end{array}$ & $\begin{array}{c}\text { None } \\
(3.0 \mathrm{E}-05)\end{array}$ & $\begin{array}{c}\text { None } \\
(1.6 \mathrm{E}-05)\end{array}$ \\
\hline $\begin{array}{l}\text { Radiological - } \\
\text { Accident Risks, } \\
\text { LCFs }\end{array}$ & \multicolumn{2}{|c|}{$\begin{array}{c}\text { None } \\
\left(1.0 \mathrm{E}-11^{(\mathrm{b})}\right)\end{array}$} \\
\hline $\begin{array}{l}\text { Nonradiological } \\
\text { Accident Risks, } \\
\text { Fatalities }\end{array}$ & $\begin{array}{c}\text { None } \\
(8.5 \mathrm{E}-05)\end{array}$ & $\begin{array}{c}\text { None } \\
(3.0 \mathrm{E}-04)\end{array}$ \\
\hline \multicolumn{3}{|c|}{ Consequences of Maximum Credible Accident } \\
\hline $\begin{array}{l}\text { Offsite } \\
\text { Population } \\
\text { Impacts, LCFs }\end{array}$ & NA & $\begin{array}{c}\text { None } \\
(1 \mathrm{E}-06)\end{array}$ \\
\hline $\begin{array}{l}\text { Collocated } \\
\text { Worker, LCFs }{ }^{(c)}\end{array}$ & $\begin{array}{l}\text { None } \\
(1 \mathrm{E}-07)\end{array}$ & NA \\
\hline $\begin{array}{l}\text { Onsite - } \\
\text { Public, LCFs } \\
\end{array}$ & NA & $\begin{array}{c}\text { None } \\
(7 \mathrm{E}-09)\end{array}$ \\
\hline $\begin{array}{l}\text { Offsite } \\
\text { Resident, } \\
\text { LCFs }^{(c, d)}\end{array}$ & NA & $2 E-09$ \\
\hline
\end{tabular}

(a) LCFs = latent cancer fatalities.

(b) Includes Hanford Site workers as well as the general public.

(c) Given as the maximum probability of contracting a fatal cancer.

(d) Includes inhalation, submersion, and groundshine pathways; does not include ingestion. 


\section{REFERENCES}

10 CFR 71. 1993. U.S. Nuclear Regulatory Commission, "Packaging and Transportation of Radioactive Material." U.S. Code of Federal Regulations.

49 CFR 173. 1993. U.S. Department of Transportation, "Shippers - General Requirements for Shipments and Packages." U.S. Code of Federal Regulations.

Beck, D. M., M. J. Scott, M. D. Davis, S. F. Shindle, B. A. Napier, A. G. Thurman, D. B. Pittinger, and N. C. Batishko. 1991. Hanford Area 1990 Population and 50-Year Projections. PNL-7803, Pacific Northwest Laboratory, Richland, Washington.

Bergsman, K. H. 1993. Hanford Irradiated Fuel Inventory Basel ine. WHC-SDCP-TI-175, Westinghouse Hanford Company, Richland, Washington.

Cashwe11, J. W., K. S. Neuhauser, P. C. Reardon, and G. W. McNair. 1986. Transportation Impacts of the Commercial Radioactive Waste Management Program. SAND85-2715, Sandia National Laboratories, Albuquerque, New Mexico.

Dunning, D. D. 1983. Estimates of Internal Dose Equivalent from Inhalation and Ingestion of Selected Radionuclides. WIPP/DOE-176, U.S. Department of Energy, Washington D.C.

Fischer, L. F., C. K. Chou, M. A. Gerhard, C. Y. Kimura, R. W. Martin, R. W. Mensing, M. E. Mount, and M. C. Witte. 1987. Shipping Container Response to Severe Highway and Railway Accident Conditions. NUREG/CR-4829, U. S. Nuclear Regulatory Commission, Washington D.C.

International Commission on Radiological Protection (ICRP). 1983. Radionuclide Transformation, Energy, and Intensity of Emissions. ICRP Publication 38, Pergammon Press, 0xford.

International Commission on Radiological Protection (ICRP). 1991. 1990 Recommendations of the International Commission on Radiological Protection. ICRP Publication 60, Pergammon Press, 0xford.

Joy, D. S., and P. E. Johnson. 1983. HIGHWAY, A Transportation Routing Model: Program Description and Revised User's Manual. ORNL/TM-8759, Oak Ridge National Laboratory, Oak Ridge, Tennessee.

Madsen, M. M., E. L. Wilmot, and J. M. Taylor. 1983. RADTRAN II User's Guide. SAND82-2681, Sandia National Laboratories, Albuquerque, New Mexico. 
Madsen, M. M., J. M. Taylor, R. M. Ostmeyer, and P. C. Reardon. 1986. RADTRAN III. SAND84-0036, Sandia National Laboratories, Albuquerque, New Mexico.

NCRP (National Council on Radiation Protection and Measurements). 1987. Exposure of the Population in the United States and Canada from Natural Background Radiation. NCRP Report No. 94, Bethesda, Maryland.

Napier, B. A.; R. A. Peloquin, D. L. Strenge, and J. V. Ramsdell. 1988. GENII - The Hanford Environmental Radiation Dosimetry Software System. PNL6584, Pacific Northwest Laboratory, Richland, Washington.

Neuhauser, K. S. and F. L. Kanipe. 1992. RADTRAN 4: Volume 3 -- User Guide. SAND89-2370, Sandia National Laboratories, ATbuquerque, New Mexico.

Neuhauser, K. S. and P. C. Reardon. 1986. A Demonstration Sensitivity Analysis for RADTRAN III. SAND85-1001, Sandia National Laboratories, Albuquerque, New Mexico.

Rao, R. K., E. L. Wilmot, and R. E. Luna. 1982. Nonradiological Impacts of Transporting Radioactive Material. SAND81-7103, Sandia National Laboratories, Albuquerque, New Mexico.

Schreckhise, R. G., K. Rhoads, J. S. Davis, B. A. Napier, and J. V. Ramsdel1. 1993. Recommended Environmental Dose Calculation Methods and Hanford-Specific Parameters. PNL-3777, Rev. 2, Pacific Northwest Laboratory, Richland, Washington.

Shibata, T., T. Tamai, and M. Hayashi. 1984. "Release of Fission Products from Irradiated Aluminide Fuel at High Temperatures." in Nuclear Science and Engineering. Vol. 87, pp. 405-417.

Stevens, P. F. 1994a. Packaging Design Criteria for the $\mathrm{N}$ Reactor/Single Pass Reactor Fuel Characterization Shipments. WHC-SD-TP-PDC-022, Rev. 0, Westinghouse Hanford Company, Richland, Washington.

Stevens, P. F. 1994b. N Reactor/Single Pass Reactor Fuel Characterization Shipments Safety Evaluation for Packaging. WHC-SD-TP-SEP-028, Westinghouse Hanford Company, Richland, Washington.

Taylor, J. M. and S. L. Daniel. 1982. RADTRAN II: A Revised Computer Code To Analyze Transportation of Radioactive Material. SAND80-1943, Sandia National Laboratories, Albuquerque, New Mexico. 
U.S. Department of Energy (DOE). 1988a. External Dose Rate Conversion Factors for Calculation of Dose to the Public. D0E/EH-0070, U.S. Department of Energy, Washington, D.C.

U.S. Department of Energy (DOE). 1988b. Internal Dose Conversion Factors for Calculation of Dose to the Public. D0E/EH-0071, U.S. Department of Energy, Washington, D.C.

U.S. Department of Energy (DOE). 1994. Department of Energy Programmatic Spent Nuclear Fuel Management and Idaho National Engineering Laboratory Environmental Restoration and Waste Management Programs Draft Environmental Impact Statement. DOE/EIS-0203-D, U.S. Department of Energy, Idaho Operations Office, Idaho Falls, Idaho.

U.S. Nuclear Regulatory Commission (NRC). 1993. Directory of Certificates of Compliance for Radioactive Material Packages. NUREG-0383, Vol. 2. Rev. 16. Washington D.C.

Wilmot, E. L. 1981. Transportation Accident Scenarios for Commercial Spent Fuel. SAND80-2124, Sandia National Laboratories, Albuquerque, New Mexico. 
APPENDIX A

COMPUTER CODE INPUT FILES 



\section{APPENDIX A}

\section{COMPUTER CODE INPUT FILES}

This appendix provides the computer code input file listings used to run the RADTRAN 4 and GENI I computer codes. The reader is referred to the RADTRAN 4 and GENII computer code manuals listed in the References for complete descriptions of the input parameters and instructions for operating the computer codes.

The contents of this Appendix is shown below to assist the reader in finding specific input files.

RADTRAN 4 Input File
GENII Input Files


RUN DATE: [ 9-AUG-94 AT 16:29:55 ]

ECHO CHECK

\&\& Edited Tue Aug 9 16:29:17 1994

\&\& SHIPMENT_OF_N_REACTOR_FUEL_FROM_K_BASIN_TO_327_BLG. TITLE PMD2 -

FORM UNIT

DIMEN $\begin{array}{lllll}24 & 6 & 4 & 10 & 18\end{array}$

PARM $1332 \begin{array}{llll}1 & 1 & 0\end{array}$

POPDEN

2.400

89.800

0.100

PACKAGE

LABGRP

SHIPMENT

PKG1

PKG4

PKG3

PKG2

LABISO

H3GAS

SB125

SM151

PU241

FE55
TE125M
EU154
AM241

C060

CS134

EU155

CM244

$\begin{array}{rr}\text { KR85 } & \text { SR90 } \\ \text { CS137 } & \text { CE144 } \\ \text { PU238 } & \text { PU239 } \\ \text { U235 } & \text { U238 }\end{array}$

RU106

PM147

PU240

NORMAL

NMODE $=1$

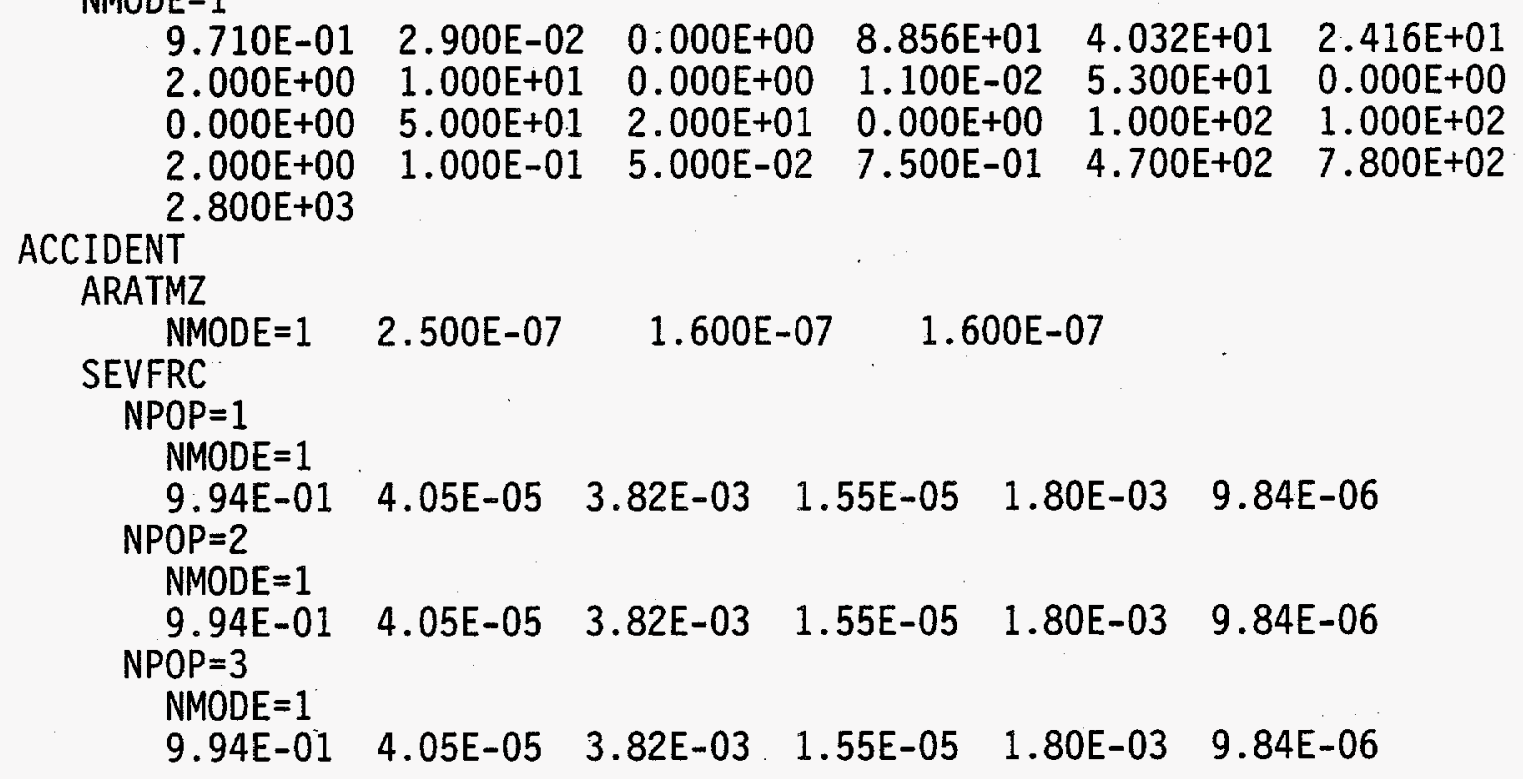




\begin{tabular}{|c|c|c|c|c|c|}
\hline \multicolumn{6}{|l|}{ ELEASE } \\
\hline GROUP $=1$ & & & & & \\
\hline $\begin{array}{l}0.00 E+00 \\
\text { GROUP }=2\end{array}$ & $9.90 \mathrm{E}-03$ & $3.30 \mathrm{E}-02$ & $3.90 \mathrm{E}-01$ & $3.30 \mathrm{E}-01$ & $6.30 \mathrm{E}-01$ \\
\hline $\begin{array}{l}0.00 E+00 \\
\text { GROUP }=3\end{array}$ & $3.00 \mathrm{E}-08$ & $1.00 \mathrm{E}-07$ & $1.00 E-06$ & $1.00 \mathrm{E}-06$ & $1.00 \mathrm{E}-05$ \\
\hline $\begin{array}{l}0.00 E+00 \\
\text { GROUP }=4\end{array}$ & $3.00 \mathrm{E}-10$ & $1.00 \mathrm{E}-09$ & $1.00 \mathrm{E}-08$ & $1.00 \mathrm{E}-08$ & $1.00 \mathrm{E}-07$ \\
\hline $\begin{array}{c}0.00 E+00 \\
\text { AEROSOL }\end{array}$ & $4.10 E-09$ & $1.40 \mathrm{E}-08$ & $2.40 \mathrm{E}-07$ & $1.40 \mathrm{E}-07$ & $2.00 E-06$ \\
\hline DISP $=2$ & & & & & \\
\hline $\begin{array}{l}0.00 E+00 \\
D I S P=4\end{array}$ & $1.00 E+00$ & $1.00 \mathrm{E}+00$ & $1.00 \mathrm{E}+00$ & $1.00 \mathrm{E}+00$ & $1.00 E+00$ \\
\hline $\begin{array}{l}0.00 E+00 \\
\text { DISP }=5\end{array}$ & $1.00 \mathrm{E}+00$ & $1.00 \mathrm{E}+00$ & $1.00 \mathrm{E}+00$ & $1.00 \mathrm{E}+00$ & $1.00 E+00$ \\
\hline $\begin{aligned} & 0.00 E+00 \\
& D I S P=7\end{aligned}$ & $1.00 E+00$ & $1.00 \mathrm{E}+00$ & $1.00 E+00$ & $1.00 E+00$ & $1.00 E+00$ \\
\hline RESP $0.00 E+00$ & $1.00 \mathrm{E}+00$ & $1.00 \mathrm{E}+00$ & $1.00 \mathrm{E}+00$ & $1: 00 E+00$ & $1.00 \mathrm{E}+00$ \\
\hline $\begin{array}{l}\text { DISP }=2 \\
0.00 E+00\end{array}$ & $1.00 E+00$ & $1.00 E+00$ & $1.00 E+00$ & $1.00 E+00$ & $1.00 E+00$ \\
\hline $\begin{array}{l}0.00 E+00 \\
\text { DISP }=5\end{array}$ & $1.00 E+00$ & $1.00 E+00$ & $1.00 E+00$ & $1.00 E+00$ & $1.00 \mathrm{E}+00$ \\
\hline $\begin{array}{l}0.00 E+00 \\
\text { DISP }=7\end{array}$ & $1.00 \mathrm{E}+00$ & $1.00 E+00$ & $1.00 E+00$ & $1.00 E+00$ & $1.00 \mathrm{E}+00$ \\
\hline $0.00 E+00$ & $1.00 \mathrm{E}+00$ & $1.00 \mathrm{E}+00$ & $1.00 E+00$ & $1.00 E+00$ & $1.00 E+00$ \\
\hline
\end{tabular}

EOF

$1.00 E+00-1.00 E+00$

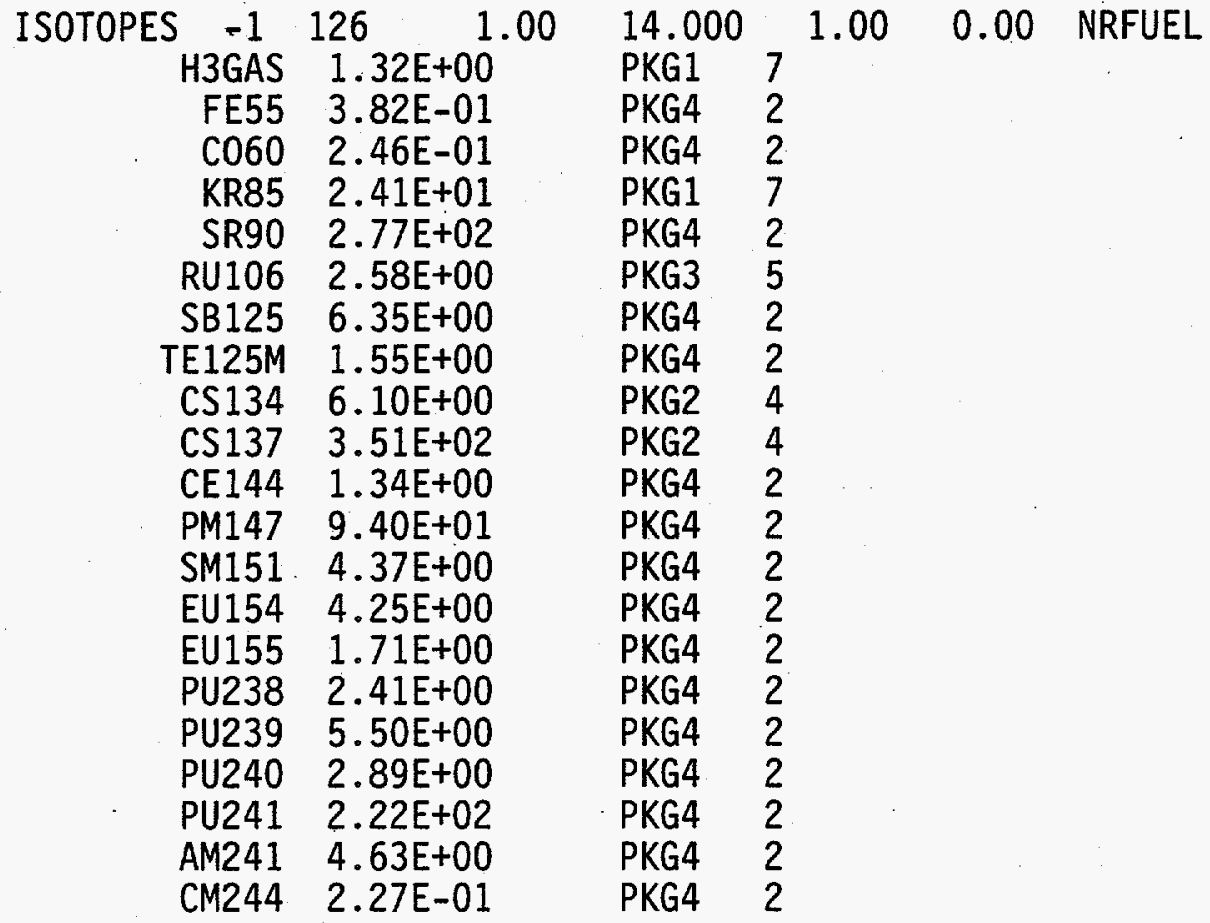




$\begin{array}{lrrrr} & \text { U235 } & 7.40 E-04 & \text { PKG4 } & 2 \\ & \text { U238 } & 1.63 E-02 & \text { PKG4 } & 2 \\ & \text { NP237 } & 1.36 E-03 & \text { PKG4 } & 2 \\ \text { DISTKM } & \text { NMODE=1 } & 45.10 & & \\ \text { PKGSIZ } & \text { NME } & & \\ \text { EOF } & \text { NRFUEL } & 2.00 & \\ \text { EOF } & & & \end{array}$


\#\#\#\#\#\#\#\#\#\#\#\#\#\#\#\#\#\#\#\#\# Program GENII Input File \#\#\#\#\#\#\#\#\#\# 8 Jul 88 \#\#\#\# Title: N Fuel - Collocated Worker

$$
\text { IGENII \case-1. in }
$$

Created on $08-24-1994$ at $14: 33$

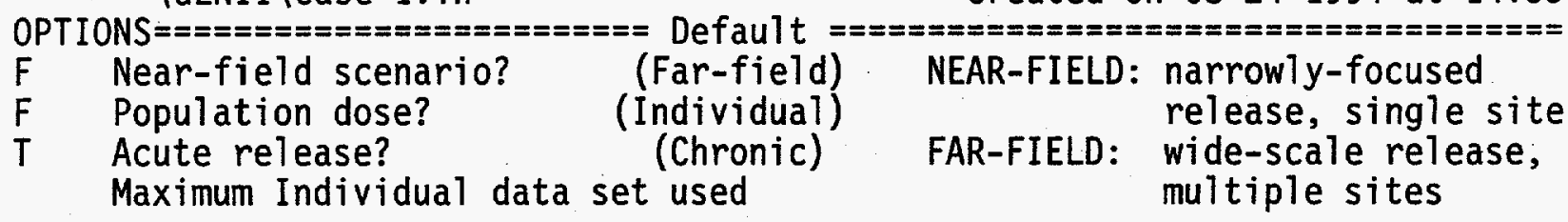

Complete

TRANSPORT OPTIONS $===========$ Section

T Air Transport

F Surface Water Transport

1
2
3,4
3,4

$F$ Waste Form Degradation (near) 3,4

\section{EXPOSURE PATHWAY OPTIONS $=====$ Section}

$\begin{array}{ll}T \text { Finite plume, external } & 5 \\ F \text { Infinite plume, external } & 5 \\ T \text { Ground, external } & 5 \\ \text { F Recreation, external } & 5\end{array}$

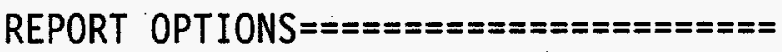

T Inhalation uptake

5,6

$T$ Report AEDE only

$T$ Report by radionuclide

F Report by exposure pathway

$F$ Debug report on screen

$\begin{array}{lll}\text { F Drinking water ingestion } & 7,8 \\ F \text { Aquatic foods ingestion } & 7,8 \\ F \text { Terrestrial foods ingestion } & 7,9 \\ F \text { Animal product ingestion } & 7,10 \\ F \text { Inadvertent soit ingestion }\end{array}$

\section{INVENTORY \#\#\#\#\#\#\#\#\#\#\#\#\#\#\#\#\#\#\#\#\#\#\#\#\#\#\#\#\#\#\#\#\#\#\#\#\#\#\#\#\#\#\#\#\#\#\#\#\#\#\#\#\#\#\#\#\#\#\#\#\#\#}

4 Inventory input activity units: (1-pCi $2-\mathrm{uCi} \quad 3-\mathrm{mCi} \quad 4-\mathrm{Ci} \quad 5-\mathrm{Bq})$

0 . Surface soil source units $(1-\mathrm{m} 22-\mathrm{m} 33-\mathrm{kg})$

Equilibrium question goes here

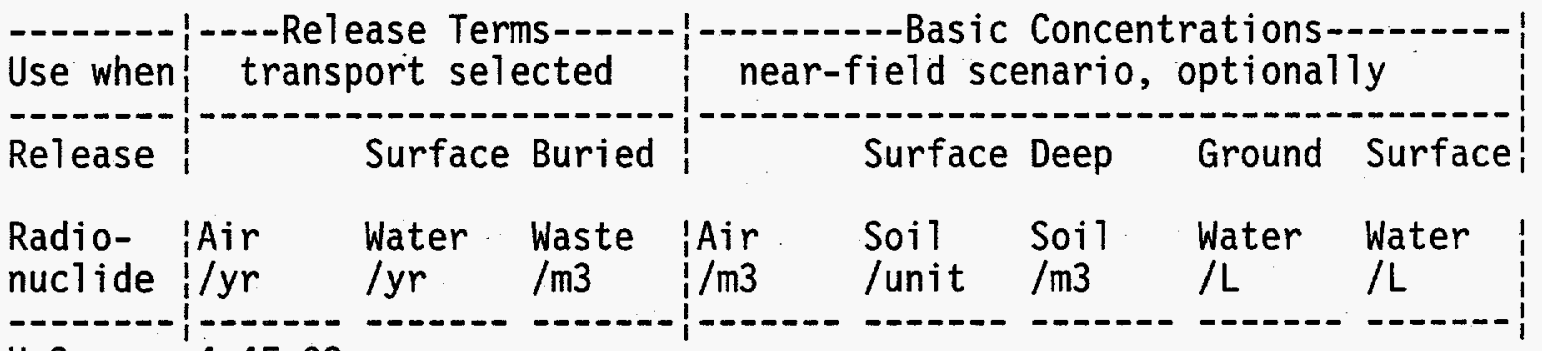

H $3 \quad 4.4 E-02$

FE55 $3.8 \mathrm{E}-10$

C060 2.5E-10

KR85 7.9E-01

SR90 2.8E-07

RU106 3.6E-08

TE125M 1.5E-09

CS134 6.1E-07

CS137 3.5E-05

CE144 1.3E-09

PR144 1.3E-09

PM147 9.4E-08

SM151 4.4E-09 


$\begin{array}{ll}\text { EU154 } & 4.2 \mathrm{E}-09 \\ \text { U 235 } & 7.4 \mathrm{E}-13 \\ \text { U 238 } & 1.6 \mathrm{E}-11 \\ \text { NP237 } & 1.4 \mathrm{E}-12 \\ \text { PU238 } & 2.4 \mathrm{E}-09 \\ \text { PU239 } & 5.5 \mathrm{E}-09 \\ \text { PU240 } & 2.9 \mathrm{E}-09 \\ \text { PU241 } & 2.2 \mathrm{E}-07 \\ \text { AM241 } & 4.6 \mathrm{E}-09 \\ \text { CM244 } & 2.3 \mathrm{E}-10\end{array}$

\begin{tabular}{l|l|l|}
\hline Use when & measured values are known \\
\hdashline Release & Terres. Animal Drink Aquatic \\
Radio- & Plant Product Water Food \\
nuclide & $/ \mathrm{kg} \quad / \mathrm{kg} \quad / \mathrm{L}$ & $/ \mathrm{kg}$ \\
&
\end{tabular}

TIME \#\#\#\#\#\#\#\#\#\#\#\#\#\#\#\#\#\#\#\#\#\#\#\#\#\#\#\#\#\#\#\#\#\#\#\#\#\#\#\#\#\#\#\#\#\#\#\#\#\#\#\#\#\#\#\#\#\#\#\#\#\#\#\#\#\#\#\#\#\#\#\#\#

1 Intake ends after (yr)

50 Dose calc. ends after (yr)

0 Release ends after (yr)

0 No. of years of air deposition prior to the intake period

0 No. of years of irrigation water deposition prior to the intake period

FAR-FIELD SCENARIOS (IF POPULATION DOSE) \#\#\#\#\#\#\#\#\#\#\#\#\#\#\#\#\#\#\#\#\#\#\#\#\#\#\#\#\#\#\#\#\#

0 Definition option: 1-Use population grid in file POP.IN

0 2-Use total entered on this line

NEAR-FIELD SCENARIOS \#\#\#\#\#\#\#\#\#\#\#\#\#\#\#\#\#\#\#\#\#\#\#\#\#\#\#\#\#\#\#\#\#\#\#\#\#\#\#\#\#\#\#\#\#\#\#\#\#\#\#\#\#\#\#

Prior to the beginning of the intake period: (yr)

$0 \quad$ When was the inventory disposed? (Package degradation starts)

$0 \quad$ When was LOIC? (Biotic transport starts)

$0 \quad$ Fraction of roots in upper soil (top $15 \mathrm{~cm}$ )

$0 \quad$ Fraction of roots in deep soil

0 Manual redistribution: deep soil/surface soil dilution factor

$0 \quad$ Source area for external dose modification factor (m2)

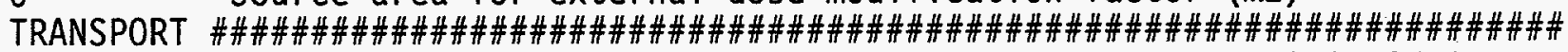

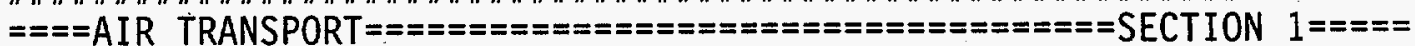

3

0 -Calculate PM

Option: 1-Use chi/Q or PM value IF 2-Select MI dist \& dir 0 3-Specify MI dist \& dir 0

$\begin{array}{ll}0 & \text { Chi/Q or } P M \text { value } \\ 14 & \text { MI sector index }(1=S)\end{array}$

0

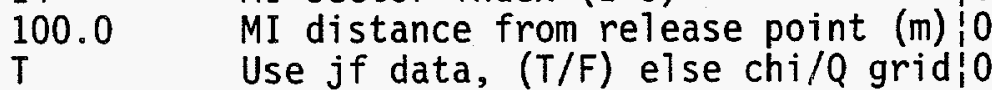

Release type $(0-3)$

Stack release $(T / F)$

Stack height (m)

Stack flow (m3/sec)

Stack radius (m)

Effluent temp. (C)

Building $x$-section (m2)

Building height (m) 


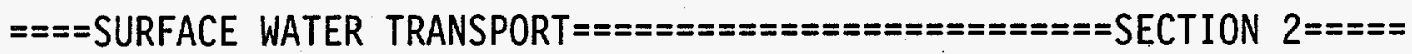

Mixing ratio model: 0 -use value, 1-river, 2-lake

Mixing ratio, dimensionless

Average river flow rate for: MIXFLG $=0(\mathrm{~m} 3 / \mathrm{s}), \operatorname{MIXFLG}=1,2(\mathrm{~m} / \mathrm{s})$,

Transit time to irrigation withdrawal location $(\mathrm{hr})$

If mixing ratio model $>0$ :

Rate of effluent discharge to receiving water body $(\mathrm{m} 3 / \mathrm{s})$

Longshore distance from release point to usage location $(\mathrm{m})$

Offshore distance to the water intake $(\mathrm{m})$

Average water depth in surface water body (m)

Average river width (m), MIXFLG=1 only

Depth of effluent discharge point to surface water (m), lake only

$====$ WASTE FORM AVAILABILITY=="=="=="==" Waste form/package half i ife, (yr)

Waste thickness, (m)

Depth of soil overburden, $m$

$====$ BIOTIC TRANSPORT OF BURIED SOURCE $==============$ SECTION $4=====$ Consider during inventory decay/buildup period (T/F)?

Consider during intake period (T/F)? 1-Arid non agricultural

Pre-Intake site condition.............. 2-Humid non agricultural 3-Agricul tural

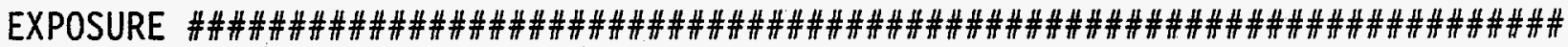

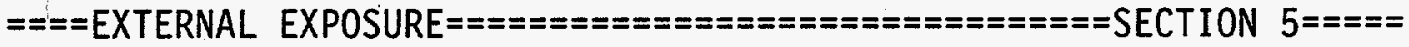
Exposure time:

0

Boating (hr)

Shorel ine activities (hr)

Residential irrigation:

$T$ Consider: (T/F)

0

Source: 1-groun

2-surface water

0

Duration (mo/yr)

Shoreline type: (1-river, 2-lake, 3-ocean, 4-tidal basin)

Transit time for release to reach aquatic recreation ( $\mathrm{hr}$ )

Average fraction of time submersed in acute cloud ( $\mathrm{hr} /$ person $\mathrm{hr}$ )

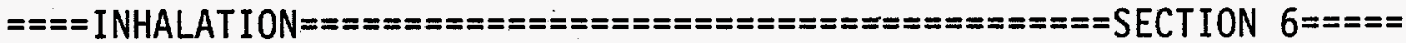
Hours of exposure to contamination per year

0 -No resus- 1 -Use Mass Loading

pension

Mass loading factor $(\mathrm{g} / \mathrm{m} 3)$

2-Use Anspaugh mode1

Top soil available $(\mathrm{cm})$

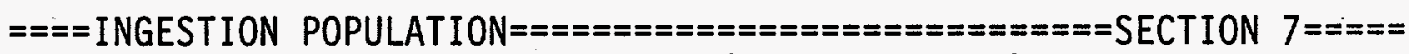
Atmospheric production definition (select option):

0

0 -Use food-weighted chi/Q, (food-sec/m3), enter value on this line 1 -Use population-weighted chi/Q

2-Use uniform production

3-Use chi/Q and production grids (PRODUCTION will be overridden)

0 Population ingesting aquatic foods, 0 defaults to total (person) Consider dose from food exported out of region (default $t=F$ ) 
Note below: $S^{*}$ or Source: 0-none, 1-ground water, 2-surface water 3-Derived concentration entered above $====$ AQUATIC FOODS / DRINKING WATER INGESTION=========SECTION $8====$

Salt water? (default is fresh)

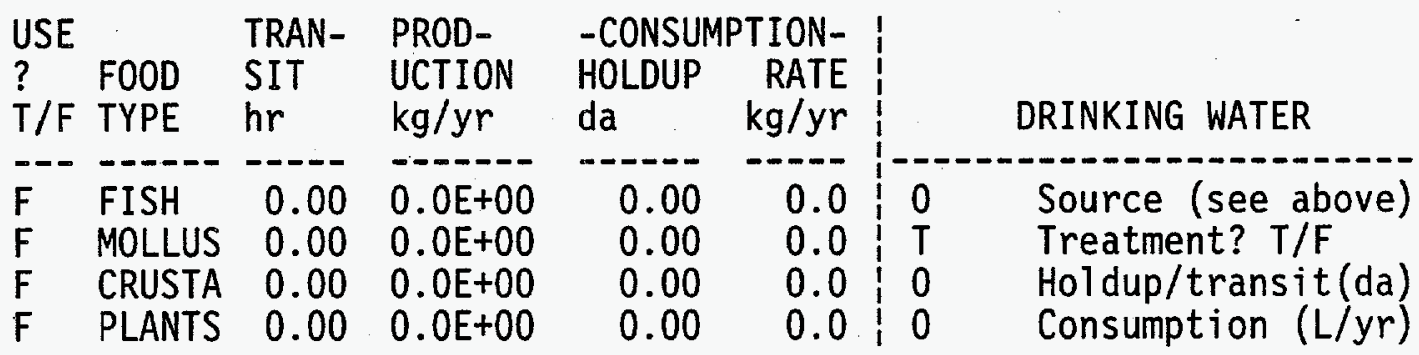

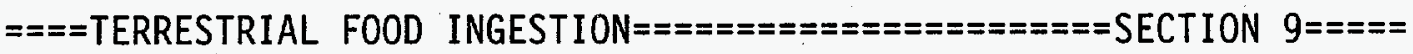

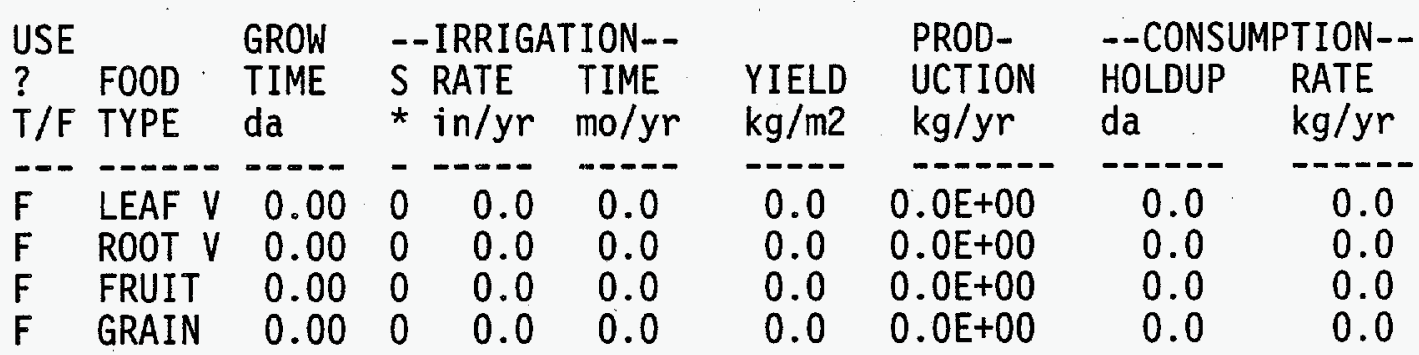


$===$ ANIMAL PRODUCTION CONSUMPTION $===================$ SECTION $10====$

\begin{tabular}{|c|c|c|c|c|c|c|c|c|c|}
\hline $\begin{array}{ll}\text { USE } & \\
? & \text { FOOD } \\
\text { T/F } & \text { TYPE }\end{array}$ & $\begin{array}{l}--- \text { HUMAN--- } \\
\text { CONSUMPTION } \\
\text { RATE HOLDUP } \\
\mathrm{kg} / \mathrm{yr} \quad \mathrm{da}\end{array}$ & $\begin{array}{l}\text { TOTAL } \\
\text { PROD- } \\
\text { UCTION } \\
\mathrm{kg} / \mathrm{yr}\end{array}$ & $\begin{array}{l}\text { DRINK } \\
\text { WATER } \\
\text { CONTAM } \\
\text { FRACT. }\end{array}$ & $\begin{array}{l}\text { DIET } \\
\text { FRAC- } \\
\text { TION }\end{array}$ & $\begin{array}{c}\text { GROW } \\
\text { TIME } \\
\text { da }\end{array}$ & $\begin{array}{l}\text {--STORED } \\
\text {-IRRIGA } \\
\text { S RATE } \\
\text { * in/yr }\end{array}$ & $\begin{array}{l}\text { TION-- } \\
\text { TIME } \\
\mathrm{mo} / \mathrm{yr}\end{array}$ & $\begin{array}{l}\text { YIELD } \\
\mathrm{kg} / \mathrm{m} 3\end{array}$ & $\begin{array}{l}\text { STOR- } \\
\text { AGE } \\
\text { da }\end{array}$ \\
\hline $\begin{array}{l}\text { BEEF } \\
\text { POULTR } \\
\text { MILK } \\
\text { EGG }\end{array}$ & $\begin{array}{rr}0.0 & 0.0 \\
0.0 & 0.0 \\
0.0 & 0.0 \\
0.0 & 0.0\end{array}$ & $\begin{array}{l}0.00 \\
0.00 \\
0.00 \\
0.00\end{array}$ & $\begin{array}{l}0.00 \\
0.00 \\
0.00 \\
0.00\end{array}$ & $\begin{array}{l}0.00 \\
0.00 \\
0.00 \\
0.00\end{array}$ & $\begin{array}{l}--. \\
0.0 \\
0.0 \\
0.0 \\
0.0\end{array}$ & $\begin{array}{lr}0 & - \\
0 & 0.0 \\
0 & 0.0 \\
0 & 0.0 \\
0 & 0.0\end{array}$ & $\begin{array}{l}0.00 \\
0.00 \\
0.00 \\
0.00\end{array}$ & $\begin{array}{l}0.00 \\
0.00 \\
0.00 \\
0.00\end{array}$ & $\begin{array}{l}0.0 \\
0.0 \\
0.0 \\
0.0\end{array}$ \\
\hline $\begin{array}{l}\text { BEEF } \\
\text { MILK }\end{array}$ & & & & $\begin{array}{l}0.00 \\
0.00\end{array}$ & $\begin{array}{l}0.0 \\
0.0\end{array}$ & $\begin{array}{l}0.0 \\
0.0\end{array}$ & $\begin{array}{l}0.00 \\
0.00\end{array}$ & $\begin{array}{l}0.00 \\
0.00\end{array}$ & $\begin{array}{l}0.0 \\
0.0\end{array}$ \\
\hline
\end{tabular}

\#\#\#\#\#\#\#\#\#\#\#\#\#\#\#\#\#\#\#\#\#\#\#\#\#\#\#\#\#\#\#\#\#\#\#\#\#\#\#\#\#\#\#\#\#\#\#\#\#\#\#\#\#\#\#\#\#\#\#\#\#\#\#\#\#\#\#\#\#\#\#\#\#\#\#\# 


$\begin{array}{ll}\text { EU154 } & 4.2 E-09 \\ \text { U 235 } & 7.4 E-13 \\ \text { U 238 } & 1.6 E-11 \\ \text { NP237 } & 1.4 E-12 \\ \text { PU238 } & 2.4 E-09 \\ \text { PU239 } & 5.5 E-09 \\ \text { PU240 } & 2.9 E-09 \\ \text { PU241 } & 2.2 E-07 \\ \text { AM241 } & 4.6 E-09 \\ \text { CM244 } & 2.3 E-10\end{array}$

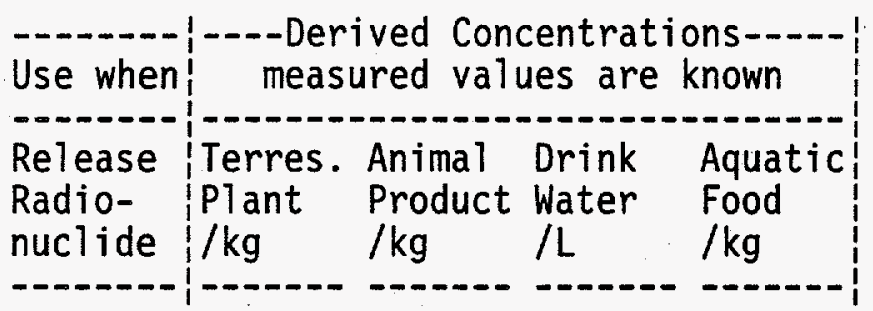

TIME \#\#\#\#\#\#\#\#\#\#\#\#\#\#\#\#\#\#\#\#\#\#\#\#\#\#\#\#\#\#\#\#\#\#\#\#\#\#\#\#\#\#\#\#\#\#\#\#\#\#\#\#\#\#\#\#\#\#\#\#\#\#\#\#

1 Intake ends after ( $y r)$

50 Dose calc. ends after $(y r)$

0 Release ends after (yr)

0 No. of years of air deposition prior to the intake period

0 No. of years of irrigation water deposition prior to the intake period

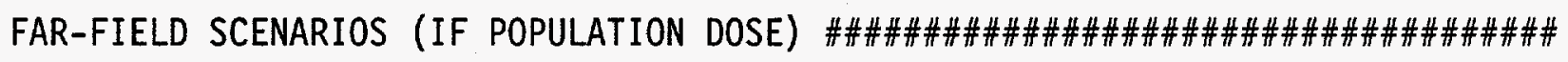

0 Definition option: 1-Use population grid in file POP.IN

$0 \quad$ 2-Use total entered on this line

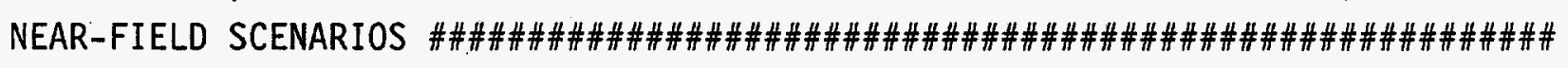

Prior to the beginning of the intake period: $(y r)$

0 . When was the inventory disposed? (Package degradation starts)

$0 \quad$ When was LOIC? (Biotic transport starts)

$0 \quad$ Fraction of roots in upper soil (top $15 \mathrm{~cm}$ )

$0 \quad$ Fraction of roots in deep soil

0 Manual redistribution: deep soil/surface soil dilution factor

$0 \quad$ Source area for external dose modification factor (m2)

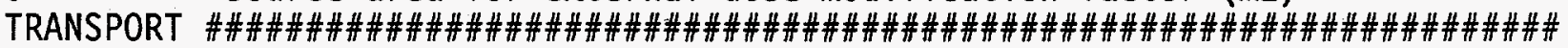
$====$ AIR TRANSPORT $================================$ SECTION $1=====$

0 -Calculate PM

Option: 1-Use chi/Q or PM value 2-Select MI dist \& dir 3-Specify MI dist \& dir

0

14

600.0

T
Chi/Q or PM value

MI sector index $(1=S)$

MI distance from release point (m) 0

Use $j f$ data, (T/F) else chi/Q grid 10
Release type $(0-3)$

Stack release $(T / F)$

Stack height (m)

Stack flow $(\mathrm{m} 3 / \mathrm{sec})$

Stack radius (m)

Effluent temp. (C)

Building x-section (m2)

Building height (m) 


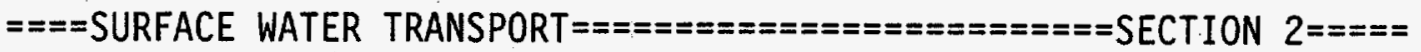
Mixing ratio model: 0 -use value, 1-river, 2-lake

Mixing ratio, dimensionless

Average river flow rate for: $\operatorname{MIXFLG}=0(\mathrm{~m} 3 / \mathrm{s}), \operatorname{MIXFLG}=1,2(\mathrm{~m} / \mathrm{s})$,

Transit time to irrigation withdrawal location (hr)

If mixing ratio model $>0$ :

Rate of effluent discharge to receiving water body $(\mathrm{m} 3 / \mathrm{s})$

Longshore distance from release point to usage location (m)

Offshore distance to the water intake (m)

Average water depth in surface water body (m)

Average river width (m), MIXFLG=1 only

Depth of effluent discharge point to surface water (m), lake only

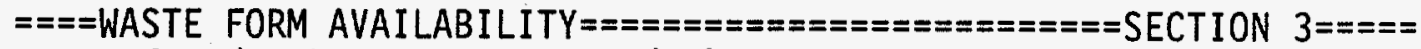
Waste form/package half life, (yr)

Waste thickness, (m)

Depth of soil overburden, $m$

$====$ BIOTIC TRANSPORT OF BURIED SOURCE $==============$ SECTION $4=====$ Consider during inventory decay/buildup period (T/F)?

Consider during intake period (T/F)? 1-Arid non agricultural

Pre-Intake site condition............ 2-Humid non agricultural

3-Agricultural

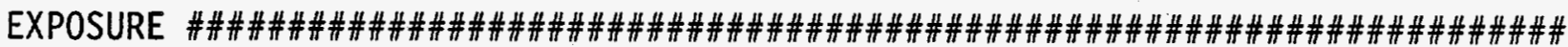

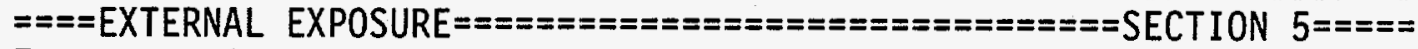
Exposure time:

2.0

0

0

0

0

0

1.0

Plume (hr)

Soil contamination (hr)

Swimming ( $h r)$

Boating (hr)

$T$ 0

Shoreline activities ( $h r)$

Shoreline type: (1-river, 2-lake, 3-ocean, 4-tidal basin)

Transit time for release to reach aquatic recreation (hr)

Average fraction of time submersed in acute cloud (hr/person hr)
2.0

0

0

0

0

0

0

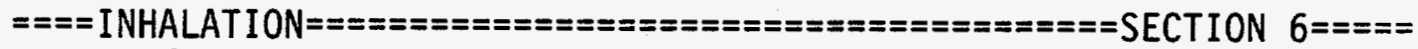
Hours of exposure to contamination per year

0 -No resus- 1-Use Mass Loading pension

Mass loading factor $(\mathrm{g} / \mathrm{m} 3)$

2-Use Anspaugh mode1

Top soil available $(\mathrm{cm})$

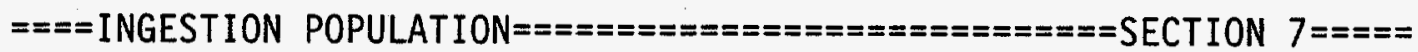
Atmospheric production definition (select option):

0 -Use food-weighted chi/Q, (food-sec/m3), enter value on this line

1-Use population-weighted chi/Q

2-Use uniform production

3-Use chi/Q and production grids (PRODUCTION will be overridden) Population ingesting aquatic foods, 0 defaults to total (person) Population ingesting drinking water, 0 defaults to total (person) Consider dose from food exported out of region (default=F) 
Note below: $S^{*}$ or Source: 0-none, 1-ground water, 2-surface water 3-Derived concentration entered above $====$ AQUATIC FOODS / DRINKING WATER INGESTION========SECTION $8====$

Salt water? (default is fresh)

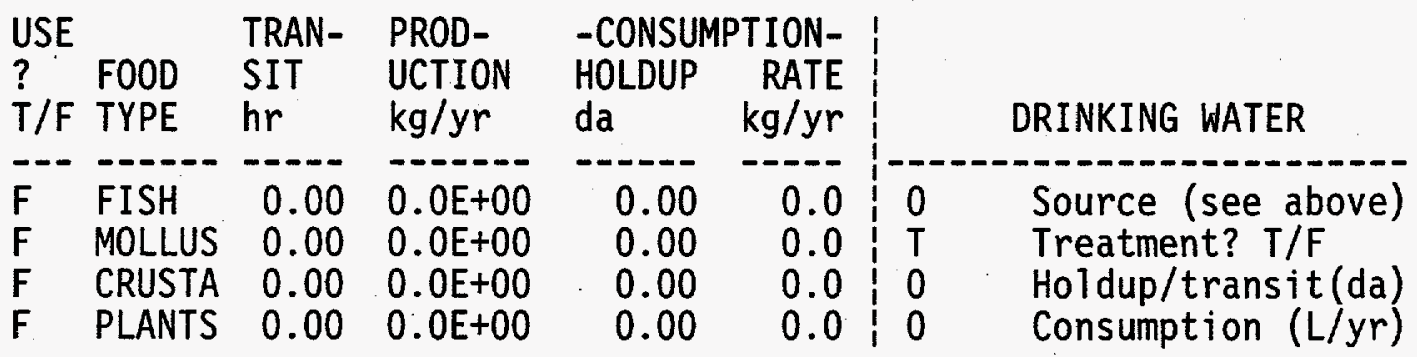

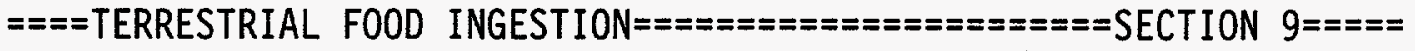

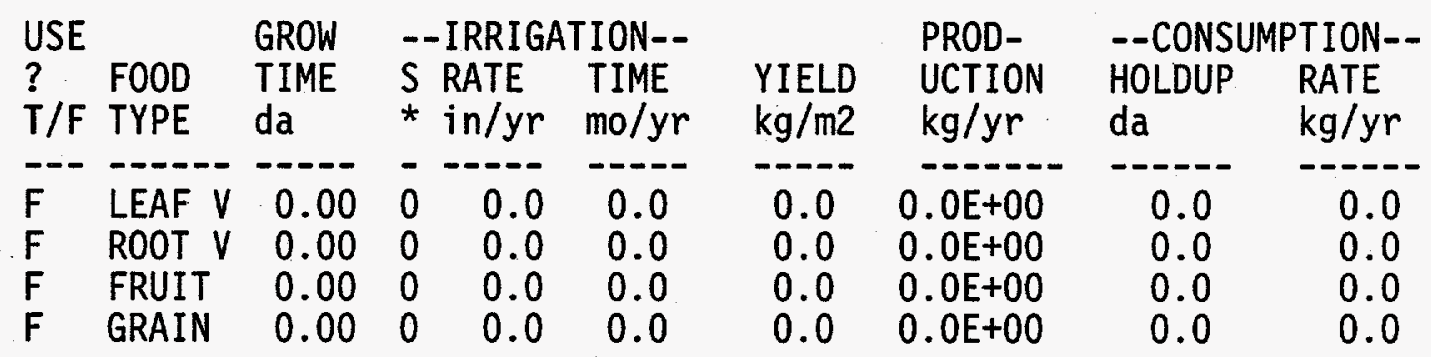


$===$ ANIMAL PRODUCTION CONSUMPTION $===================$ SECTION $10====$

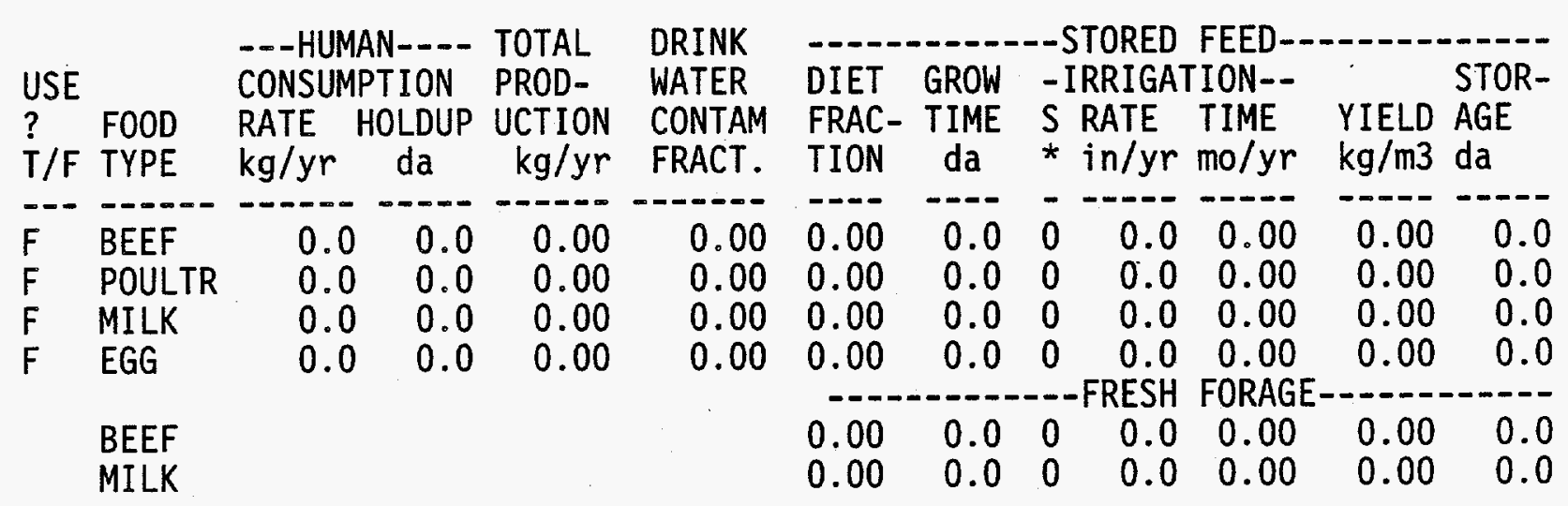

\#\#\#\#\#\#\#\#\#\#\#\#\#\#\#\#\#\#\#\#\#\#\#\#\#\#\#\#\#\#\#\#\#\#\#\#\#\#\#\#\#\#\#\#\#\#\#\#\#\#\#\#\#\#\#\#\#\#\#\#\#\#\#\#\#\#\#\#\#\# 
\#\#\#\#\#\#\#\#\#\#\#\#\#\#\#\#\#\#\#\#\#\# Program GENII Input File \#\#\#\#\#\#\#\#\#\# 8 Jul 88 \#\#\# Title: N Fuel - Offsite Resident

IGENII\case-3.in

Created on $08-24-1994$ at $14: 38$

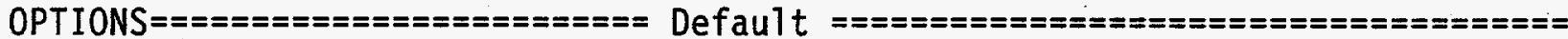

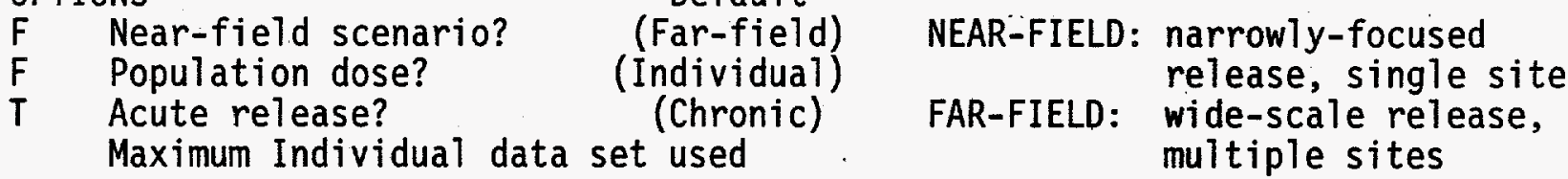

Complete

TRANSPORT OPTIONS============ Section

Complete

$T$ Air Transport

F Surface Water Transport

1
3,4
3,4

$F$ Waste Form Degradation (near) 3,4

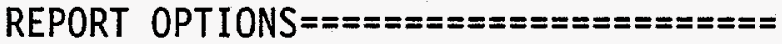

$T$ Report AEDE only

$T$ Report by radionuclide

F Report by exposure pathway

$F$ Debug report on screen

EXPOSURE PATHWAY OPTIONS $=====$ Section

$T$ Finite plume, external 5

F Infinite plume, external 5

$T$ Ground, external 5

F Recreation, external 5

$T$ Inhalation uptake $\quad 5,6$

$F$ Drinking water ingestion 7,8

$F$ Aquatic foods ingestion 7,8

$F$ Terrestrial foods ingestion 7,9

$F$ Animal product ingestion 7,10

$F$ Inadvertent soil ingestion

INVENTORY \#\#\#\#\#\#\#\#\#\#\#\#\#\#\#\#\#\#\#\#\#\#\#\#\#\#\#\#\#\#\#\#\#\#\#\#\#\#\#\#\#\#\#\#\#\#\#\#\#\#\#\#\#\#\#\#\#\#\#\#\#\#

4 Inventory input activity units: (1-pCi $2-\mathrm{uCi} \quad 3-\mathrm{mCi} \quad 4-\mathrm{Ci} \quad 5-\mathrm{Bq})$

0 Surface soil source units (1- $\mathrm{m} 2 \quad 2-\mathrm{m} 3 \quad 3-\mathrm{kg})$

Equilibrium question goes here

\begin{tabular}{l|c|c|}
\hline Use when & transport selected & near-field scenario, optional1y \\
\hline Release & Surface Buried & Surface Deep Ground Surface
\end{tabular}

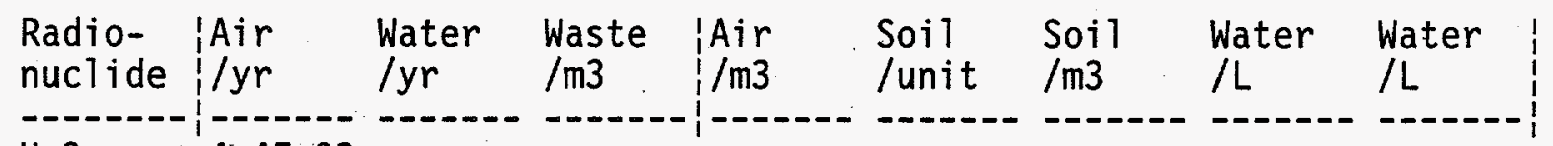

H 3 4.4E-02

FE55 $\quad 3.8 \mathrm{E}-10$

C060 2.5E-10

KR85 7.9E-01

SR90 2.8E-07

RU106 3.6E-08

TE125M 1.5E-09

CS134 . 6.1E-07

CS137 3.5E-05

CE144 1.3E-09

PR144 1.3E-09

PM147 9.4E-08

SM151 4.4E-09 


$\begin{array}{ll}\text { EU154 } & 4.2 \mathrm{E}-09 \\ \text { U 235 } & 7.4 \mathrm{E}-13 \\ \text { U 238 } & 1.6 \mathrm{E}-11 \\ \text { NP237 } & 1.4 \mathrm{E}-12 \\ \text { PU238 } & 2.4 \mathrm{E}-09 \\ \text { PU239 } & 5.5 \mathrm{E}-09 \\ \text { PU240 } & 2.9 \mathrm{E}-09 \\ \text { PU241 } & 2.2 \mathrm{E}-07 \\ \text { AM241 } & 4.6 \mathrm{E}-09 \\ \text { CM244 } & 2.3 \mathrm{E}-10\end{array}$

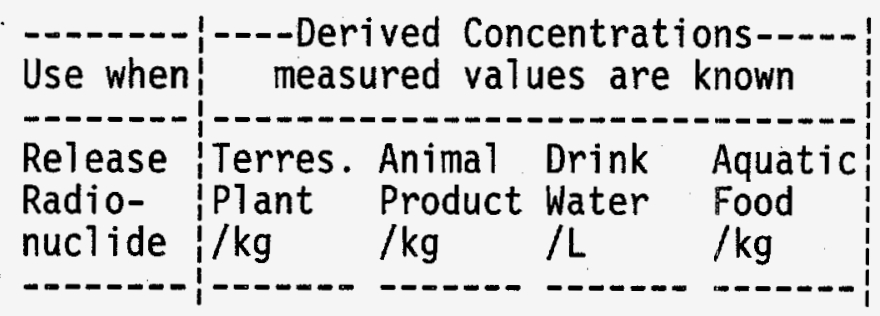

\section{TIME \#\#\#\#\#\#\#\#\#\#\#\#\#\#\#\#\#\#\#\#\#\#\#\#\#\#\#\#\#\#\#\#\#\#\#\#\#\#\#\#\#\#\#\#\#\#\#\#\#\#\#\#\#\#\#\#\#\#\#\#\#\#\#\#\#\#\#\#\#\#\#}

1 Intake ends after (yr)

50 Dose calc. ends after (yr)

0 . Release ends after (yr)

0 . No. of years of air deposition prior to the intake period

0 No. of years of irrigation water deposition prior to the intake period

\section{FAR-FIELD SCENARIOS (IF POPULATION DOSE) \#\#\#\#\#\#\#\#\#\#\#\#\#\#\#\#\#\#\#\#\#\#\#\#\#\#\#\#\#\#\#\#\#\#}

0 Definition option: 1-Use population grid in file POP. IN

0 2-Use total entered on this line

NEAR-FIELD SCENARIOS \#\#\#\#\#\#\#\#\#\#\#\#\#\#\#\#\#\#\#\#\#\#\#\#\#\#\#\#\#\#\#\#\#\#\#\#\#\#\#\#\#\#\#\#\#\#\#\#\#\#

Prior to the beginning of the intake period: (yr)

$0 \quad$ When was the inventory disposed? (Package degradation starts)

$0 \quad$ When was LOIC? (Biotic transport starts)

0 Fraction of roots in upper soil (top $15 \mathrm{~cm}$ )

0 Fraction of roots in deep soil

0 Manual redistribution: deep soil/surface soil dilution factor

$0 \quad$ Source area for external dose modification factor (m2)

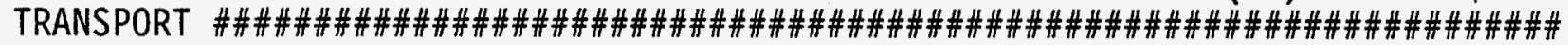

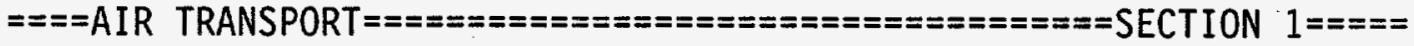

$\begin{array}{ll:l} & \text { 0-Calculate PM } & 0 \\ & \text { Option: } 1 \text {-Use chi/Q or PM value } & F \\ & 2-S e l e c t \text { MI dist \& dir } & 0 \\ & 3-S p e c i f y ~ M I \text { dist \& dir } & 0 \\ 0 & \text { Chi/Q or PM value } & 0 \\ 14 & \text { MI sector index }(I=S) & 0\end{array}$

1400. MI distance from release point $(\mathrm{m})$ $T \quad$ Use jf data, (T/F) else chi/Q grid/0

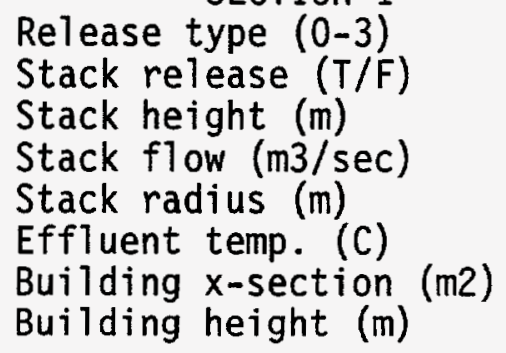




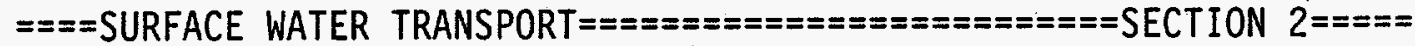
Mixing ratio model: 0-use value, 1-river, 2-lake Mixing ratio, dimensionless

Average river flow rate for: $\operatorname{MIXFLG}=0(\mathrm{~m} 3 / \mathrm{s}), \operatorname{MIXFLG}=1,2(\mathrm{~m} / \mathrm{s})$, Transit time to irrigation withdrawal location (hr) If mixing ratio model $>0$ :

Rate of effluent discharge to receiving water body $(\mathrm{m} 3 / \mathrm{s})$

Longshore distance from release point to usage location (m)

offshore distance to the water intake (m)

Average water depth in surface water body (m)

Average river width (m), MIXFLG $=1$ only

Depth of effluent discharge point to surface water (m), lake only

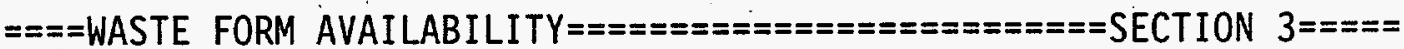
Waste form/package half life, (yr)

Waste thickness, (m)

Depth of soil overburden, $m$

$====$ BIOTIC TRANSPORT OF BURIED SOURCE==s=s=s=s==s====SECTION $4=====$ Consider during inventory decay/buildup period (T/F)?

Consider during intake period (T/F)? 1-Arid non agricultural

Pre-Intake site condition.............. 2-Humid non agricultural 3-Agricul tural

\#\#\#\#\#\#\#\#\#\#\#\#\#\#\#\#\#\#\#\#\#\#\#\#\#\#\#\#\#\#\#\#\#\#\#\#\#\#\#\#\#\#\#\#\#\#\#\#\#\#\#\#\#\#\#\#\#\#\#\#\#\#\#\# $====$ EXTERNAL EXPOSURE $==============================$ SECTION $5=====$

Exposure time:

Plume (hr)

Soil contamination (hr)

Swimming (hr)

Boating ( $h r$ )

Shoreline activities ( $h r)$

Residential irrigation:

$T$ Consider: (T/F)

0 Source: 1-ground water

2-surface water

$0 \quad$ Application rate (in/yr)

Shoreline type. (1-river, 2-lake, 3-ocean, 4-tidal basin)

Transit time for release to reach aquatic recreation $(\mathrm{hr})$

Average fraction of time submersed in acute cloud ( $\mathrm{hr} / \mathrm{person} \mathrm{hr}$ )

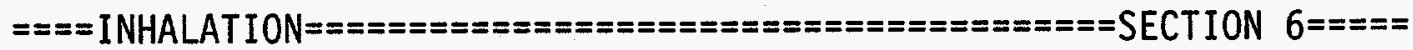
Hours of exposure to contamination per year

0 -No resus- 1-Use Mass Loading pension Mass loading factor $(\mathrm{g} / \mathrm{m} 3)$

2-Use Anspaugh model Top soil available $(\mathrm{cm})$

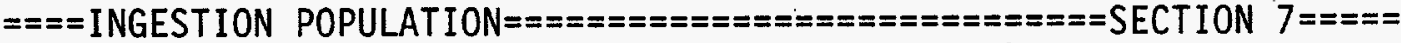
Atmospheric production definition (select option):

0 -Use food-weighted chi/Q, (food-sec/m3), enter value on this line 1-Use population-weighted chi/Q

2-Use uniform production

3-Use chi/Q and production grids (PRODUCTION will be overridden) Population ingesting aquatic foods, 0 defaults to total (person) Population ingesting drinking water, 0 defaults to total (person) Consider dose from food exported out of region (default=F) 
Note below: $S^{*}$ or Source: 0-none, 1-ground water, 2-surface water 3-Derived concentration entered above $====$ AQUATIC FOODS / DRINKING WATER INGESTION=========SECTION $8====$

Salt water? (default is fresh)

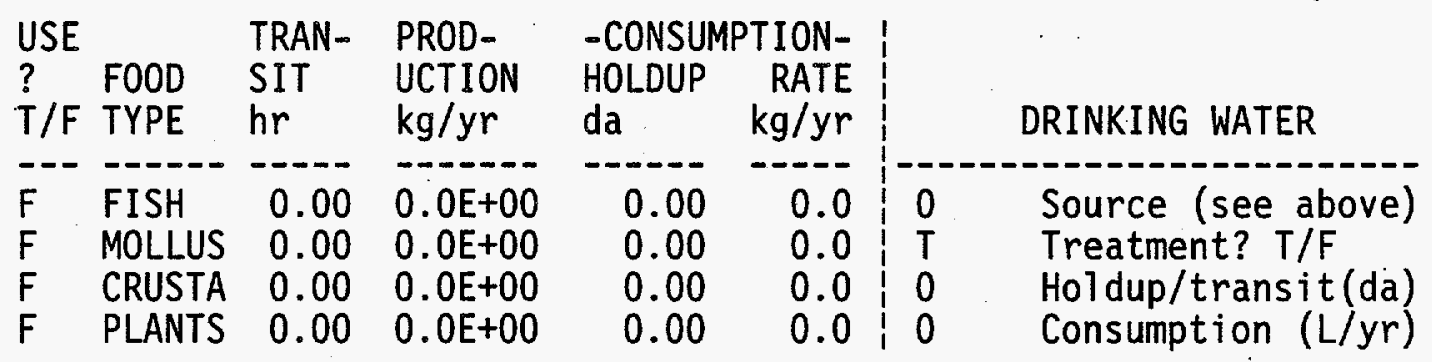

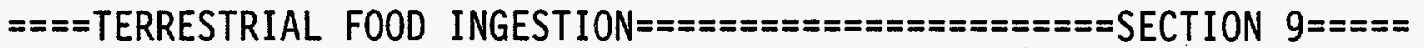

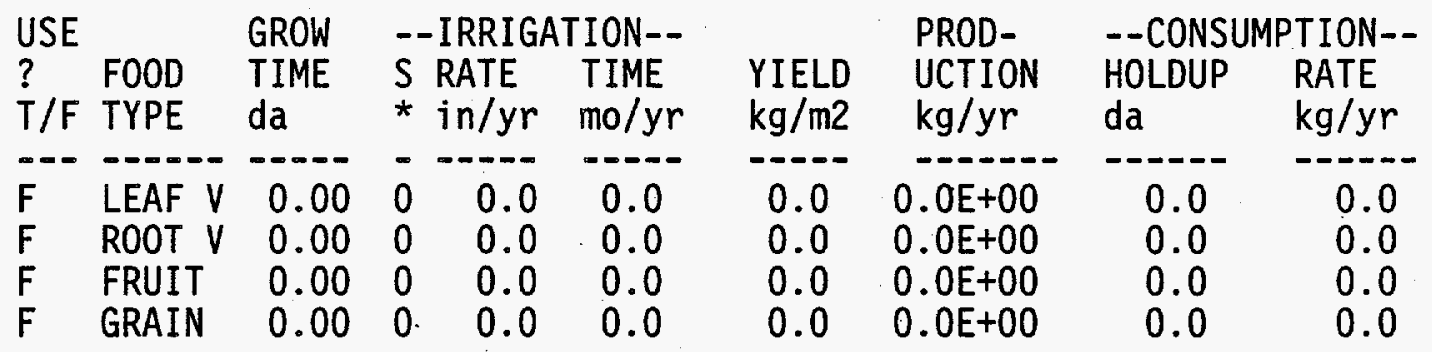




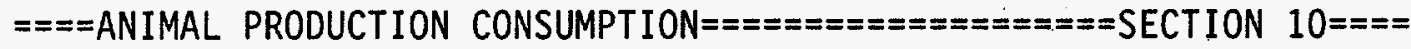

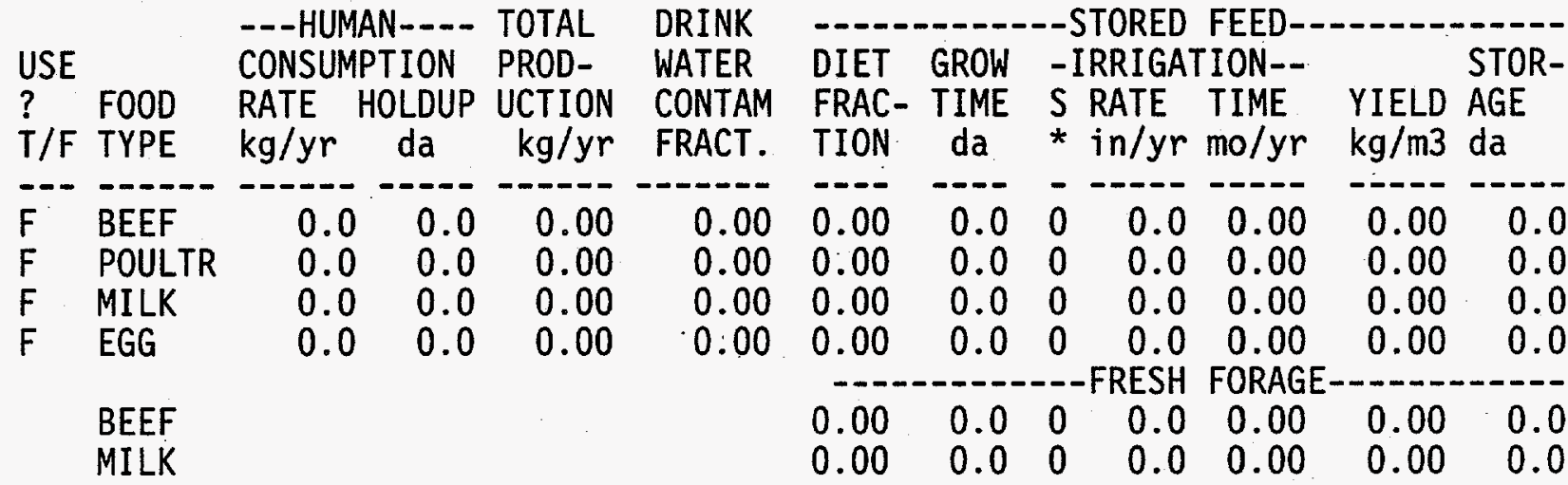

\#\#\#\#\#\#\#\#\#\#\#\#\#\#\#\#\#\#\#\#\#\#\#\#\#\#\#\#\#\#\#\#\#\#\#\#\#\#\#\#\#\#\#\#\#\#\#\#\#\#\#\#\#\#\#\#\#\#\#\#\#\#\#\#\#\#\#\#\#\#\#\#\#\#\#\#\# 
\#\#\#\#\#\#\#\#\#\#\#\#\#\#\#\#\#\#\#\#\# Program GENII Input File \#\#\#\#\#\#\#\#\#\# 8 Jul 88 \#\#\#\# Title: N Fuel - Offsite Resident; Ingestion Pathway IGENI I\case-4. in

Created on 08-24-1994 at 14:40

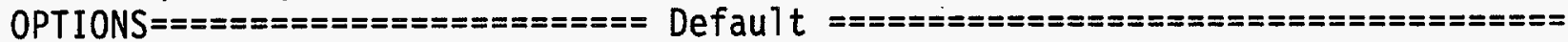

$\begin{array}{ccccc}\text { F } & \text { Near-field scenario? } & \text { (Far-field) } & \text { NEAR-FIELD: narrowly-focused } \\ \text { F } & \text { Population dose? } & \text { (Individual) } & \text { release, single site } \\ \text { T } & \begin{array}{l}\text { Acute release? } \\ \text { Maximum Individual data set used }\end{array} & \text { FAR-FIELD: } & \begin{array}{l}\text { wide-scale release, } \\ \text { multiple sites }\end{array}\end{array}$

Complete

TRANSPORT OPTIONS $============$ Section

Complete

T Air Transport
$F$ Surface Water Transport
$F$ Biotic Transport (near-fie
$F$ Waste Form Degradation (near)
REPORT OPTIONS===============
$T$ Report AEDE only
$T$ Report by radionuclide
$F$ Report by exposure pathway
$F$ Debug report on screen

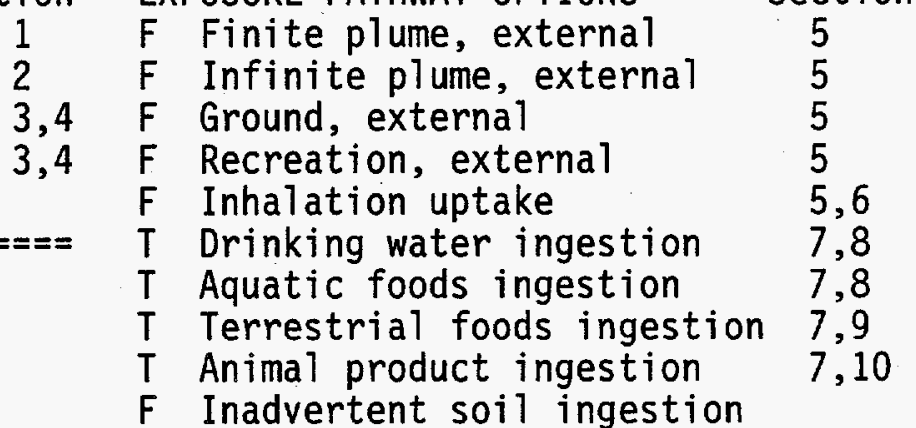

INVENTORY \#\#\#\#\#\#\#\#\#\#\#\#\#\#\#\#\#\#\#\#\#\#\#\#\#\#\#\#\#\#\#\#\#\#\#\#\#\#\#\#\#\#\#\#\#\#\#\#\#\#\#\#\#\#\#\#\#\#\#\#\#\#\#\#

4 Inventory input activity units: (1-pCi $2-\mathrm{uCi} \quad 3-\mathrm{mCi} \quad 4-\mathrm{Ci} \quad 5-\mathrm{Bq})$

0 Surface soil source units $(1-\mathrm{m} 2 \quad 2-\mathrm{m} 3 \quad 3-\mathrm{kg})$

Equilibrium question goes here

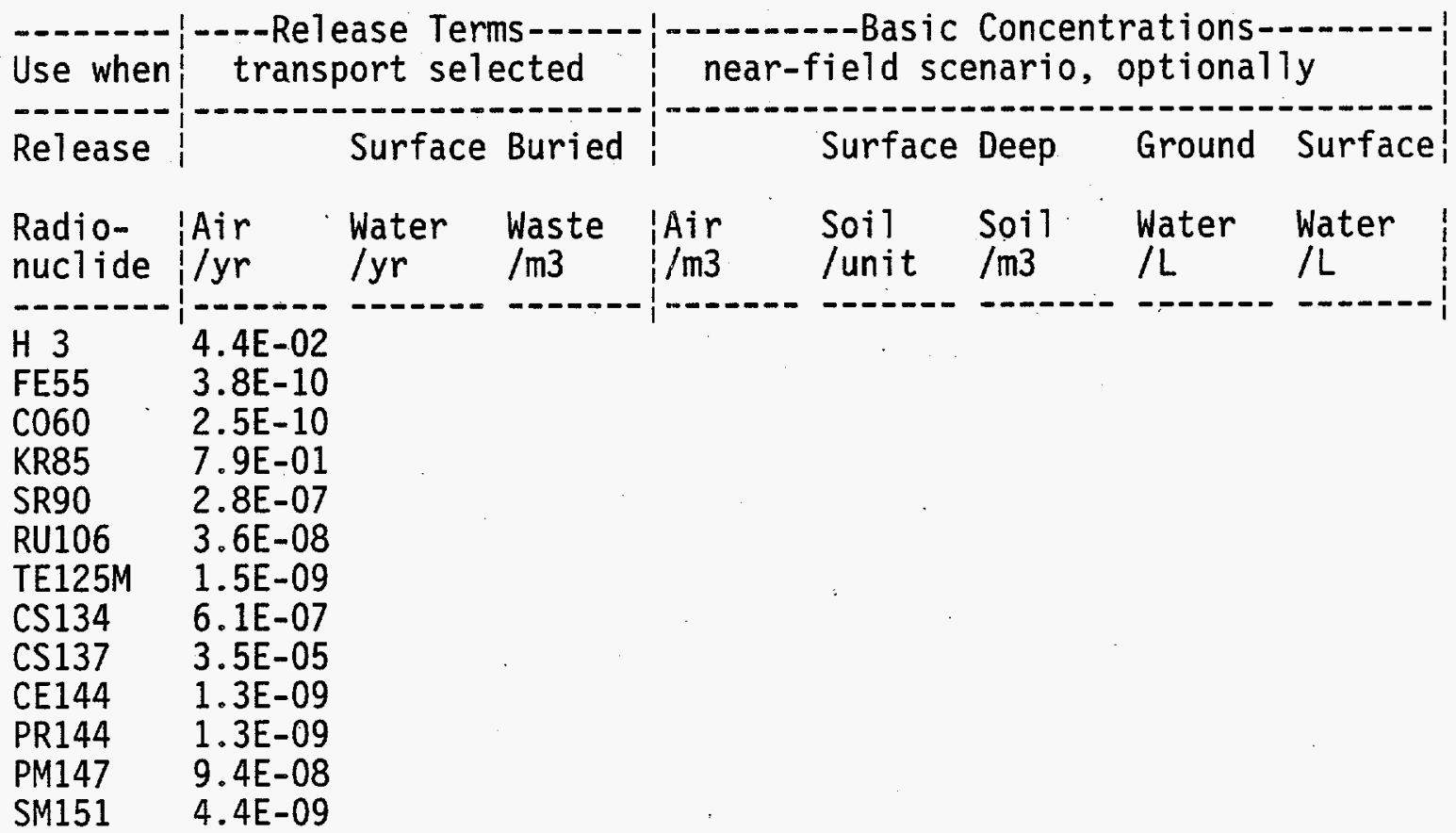




$\begin{array}{ll}\text { EU154 } & 4.2 \mathrm{E}-09 \\ \text { U 235 } & 7.4 \mathrm{E}-13 \\ \text { U 238 } & 1.6 \mathrm{E}-11 \\ \text { NP237 } & 1.4 \mathrm{E}-12 \\ \text { PU238 } & 2.4 \mathrm{E}-09 \\ \text { PU239 } & 5.5 \mathrm{E}-09 \\ \text { PU240 } & 2.9 \mathrm{E}-09 \\ \text { PU241 } & 2.2 \mathrm{E}-07 \\ \text { AM241 } & 4.6 \mathrm{E}-09 \\ \text { CM244 } & 2.3 \mathrm{E}-10\end{array}$

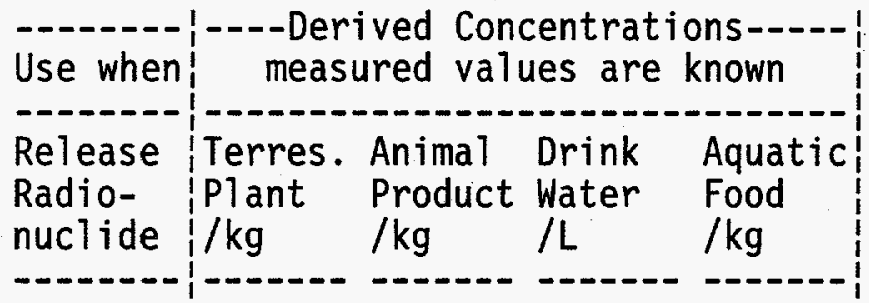

TIME \#\#\#\#\#\#\#\#\#\#\#\#\#\#\#\#\#\#\#\#\#\#\#\#\#\#\#\#\#\#\#\#\#\#\#\#\#\#\#\#\#\#\#\#\#\#\#\#\#\#\#\#\#\#\#\#\#\#\#\#\#\#\#\#\#\#\#\#\#

$1 \quad$ Intake ends after (yr)

50 Dose calc. ends after (yr)

0 Release ends after (yr)

0 No. of years of air deposition prior to the intake period

0 No. of years of irrigation water deposition prior to the intake period

FAR-FIELD SCENARIOS (IF POPULATION DOSE) \#\#\#\#\#\#\#\#\#\#\#\#\#\#\#\#\#\#\#\#\#\#\#\#\#\#\#\#\#\#\#\#\#\#

0 Definition option: 1-Use population grid in file POP.IN

0

2-Use total entered on this line

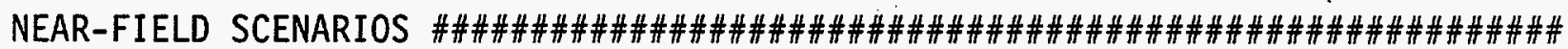

Prior to the beginning of the intake period: (yr)

0 When was the inventory disposed? (Package degradation starts)

$0 \quad$ When was LOIC? (Biotic transport starts)

$0 \quad$ Fraction of roots in upper soil (top $15 \mathrm{~cm}$ )

0 Fraction of roots in deep soil

0 Manual redistribution: deep soil/surface soil dilution factor

$0 \quad$ Source area for external dose modification factor (m2)

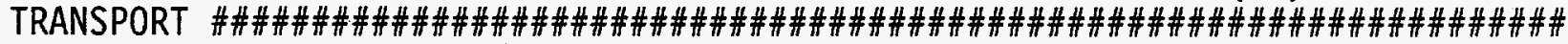

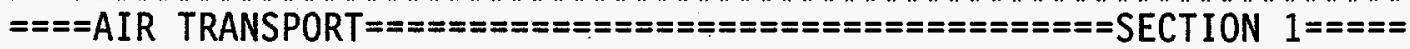

3 0-Calculate PM $0 \quad$ Release type (0-3)

3 Option: 1-Use chi/Q or PM value IF Stack release (T/F)

2-Select MI dist \& dir 0 Stack height (m)

3-Specify MI dist \& dir 10 Stack flow $(\mathrm{m} 3 / \mathrm{sec})$

$\begin{array}{lll}0 & \text { Chi } / Q \text { or PM value } & 0 \\ 14 & \text { MI sector index }(1=S)\end{array}$

Stack radius $(\mathrm{m})$

Effluent temp. (C)

1400. MI distance from release point $(\mathrm{m})$

Building $x$-section (m2)

$\mathrm{T}$ Use $\mathrm{jf}$ data, (T/F) else chi/Q gridi 0

Building height $(\mathrm{m})$ 


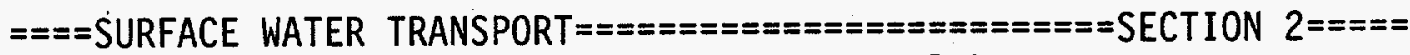

Mixing ratio model: 0-use value, 1-river, 2-lake

Mixing ratio, dimensionless

Average river flow rate for: MIXFLG $=0(\mathrm{~m} 3 / \mathrm{s}), \operatorname{MIXFLG}=1,2(\mathrm{~m} / \mathrm{s})$,

Transit time to irrigation withdrawal location $(\mathrm{hr})$

If mixing ratio model $>0$ :

Rate of effluent discharge to receiving water body $(\mathrm{m} 3 / \mathrm{s})$

Longshore distance from release point to usage location (m)

offshore distance to the water intake (m)

Average water depth in surface water body (m)

Average river width (m), MIXFLG $=1$ only

Depth of effluent discharge point to surface water $(m)$, lake only

$====$ WASTE FORM AVAILABILITY $=========================$ SECTION $3=====$ Waste form/package half life, (yr)

Waste thickness, (m)

Depth of soil overburden, $m$

$====$ BIOTIC TRANSPORT OF BURIED SOURCE $===============$ SECTION $4=====$ Consider during inventory decay/buildup period (T/F)?

Consider during intake period (T/F)? | 1-Arid non agricultural

Pre-Intake site condition............ 2-Humid non agricultural

3-Agricultural

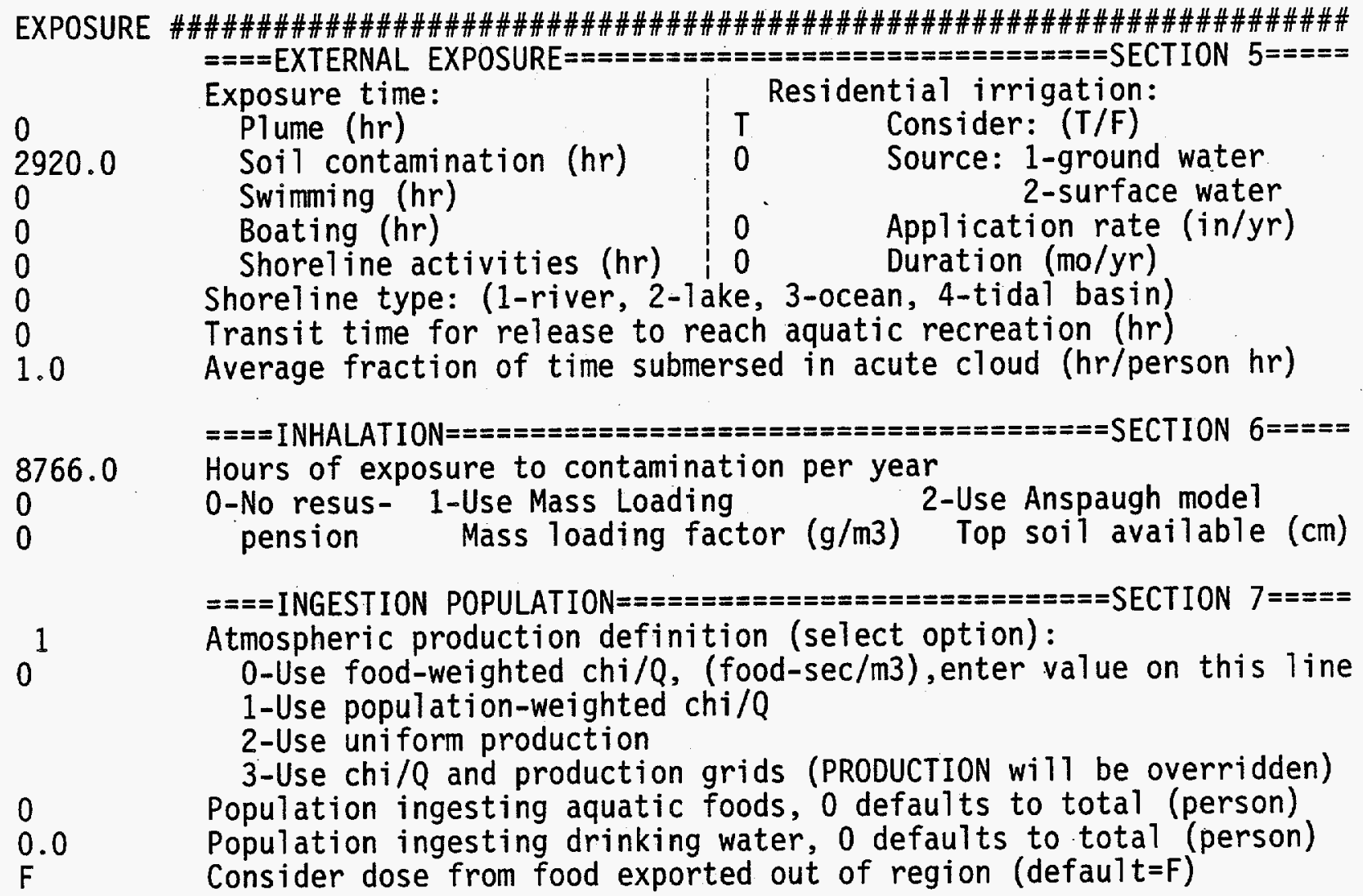


Note below: $S^{*}$ or Source: 0-none, 1-ground water, 2-surface water 3-Derived concentration entered above $====$ AQUATIC FOODS / DRINKING WATER INGESTION $========$ SECTION $8====$

Salt water? (default is fresh)

\begin{tabular}{|c|c|c|c|c|c|c|}
\hline $\begin{array}{ll}\text { USE } & \\
\stackrel{?}{\text { T }} & \text { FOOD } \\
\text { TYPE }\end{array}$ & $\begin{array}{l}\text { TRAN- } \\
\text { SIT } \\
\mathrm{hr}\end{array}$ & $\begin{array}{l}\text { PROD- } \\
\text { UCTION } \\
\mathrm{kg} / \mathrm{yr}\end{array}$ & $\begin{array}{l}\text { - CONSUM } \\
\text { HOLDUP } \\
\text { da }\end{array}$ & $\begin{array}{l}\text { TION- } \\
\text { RATE } \\
\mathrm{kg} / \mathrm{yr}\end{array}$ & & DRINKING WATER \\
\hline $\begin{array}{l}\text { FISH } \\
\text { MOLLUS } \\
\text { CRUSTA } \\
\text { PLANTS }\end{array}$ & $\begin{array}{l}0.00 \\
0.00 \\
0.00 \\
0.00\end{array}$ & $\begin{array}{l}0.0 E+00 \\
0.0 E+00 \\
0.0 E+00 \\
0.0 E+00\end{array}$ & $\begin{array}{l}1.00 \\
0.00 \\
0.00 \\
0.00\end{array}$ & $\begin{array}{r}40.0 \\
6.9 \\
6.9 \\
6.9\end{array}$ & $\begin{array}{l}0 \\
T \\
1.0 \\
730.0\end{array}$ & $\begin{array}{l}\text { Source (see above) } \\
\text { Treatment? T/F } \\
\text { Holdup/transit(da) } \\
\text { Consumption (L/yr) }\end{array}$ \\
\hline
\end{tabular}

$====$ TERRESTRIAL FOOD INGESTION=="=="=="=="=="=="==="==SECTION $9=====$

\begin{tabular}{|c|c|c|c|c|c|c|c|}
\hline & GROW & \multicolumn{2}{|c|}{--IRRIGATION-- } & \multirow[b]{2}{*}{$\begin{array}{l}Y \text { IELD } \\
\mathrm{kg} / \mathrm{m} 2\end{array}$} & \multirow{2}{*}{$\begin{array}{l}\text { PROD- } \\
\text { UCTION } \\
\mathrm{kg} / \mathrm{yr}\end{array}$} & \multicolumn{2}{|c|}{--CONSUMPTION-- } \\
\hline $\begin{array}{l}\text { FOOD } \\
\text { TYPE }\end{array}$ & $\begin{array}{l}\text { TIME } \\
\mathrm{da}\end{array}$ & $\begin{array}{l}\text { S RATE } \\
* \text { in/yr }\end{array}$ & $\begin{array}{l}\text { TIME } \\
\mathrm{mo} / \mathrm{yr}\end{array}$ & & & $\begin{array}{l}\text { HOLDUP } \\
\text { da }\end{array}$ & $\begin{array}{l}\text { RATE } \\
\mathrm{kg} / \mathrm{yr}\end{array}$ \\
\hline & $\begin{array}{l}90.00 \\
90.00 \\
90.00\end{array}$ & $\begin{array}{l}0.0 \\
0.0 \\
0.0 \\
0.0\end{array}$ & $\begin{array}{l}0.0 \\
0.0 \\
0.0 \\
0.0\end{array}$ & $\begin{array}{l}1.5 \\
4.0 \\
2.0 \\
0.8\end{array}$ & $\begin{array}{l}0.0 E+00 \\
0.0 E+00 \\
0.0 E+00 \\
0.0 E+00\end{array}$ & $\begin{array}{r}1.0 \\
5.0 \\
5.0 \\
180.0\end{array}$ & $\begin{array}{r}30.0 \\
220.0 \\
330.0 \\
80.0\end{array}$ \\
\hline
\end{tabular}


$===$ ANIMAL PRODUCTION CONSUMPTION $==================$ SECTION $10====$

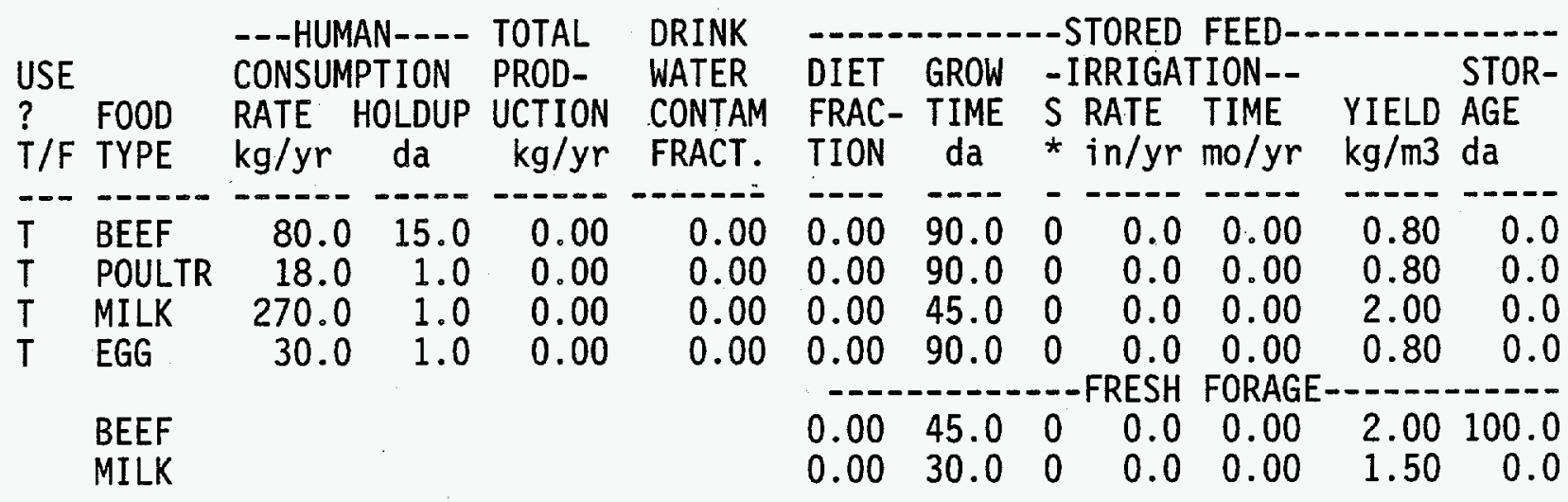

\#\#\#\#\#\#\#\#\#\#\#\#\#\#\#\#\#\#\#\#\#\#\#\#\#\#\#\#\#\#\#\#\#\#\#\#\#\#\#\#\#\#\#\#\#\#\#\#\#\#\#\#\#\#\#\#\#\#\#\#\#\#\#\#\#\#\#\#\# 
\#\#\#\#\#\#\#\#\#\#\#\#\#\#\#\#\#\#\#\#\#\# Program GENII Input File \#\#\#\#\#\#\#\#\#\# 8 Jul 88 \#\#\#\# Title: N-Fue1 - Population Dose IGENII \nfuel-7.in

Created on $08-10-1994$ at $10: 35$

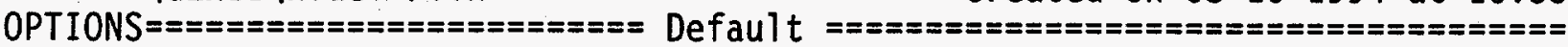
F Near-field scenario? (Far-field) T Population dose? (Individual)

T Acute release? Average Individual data set used

NEAR-FIELD: narrowly-focused release, single site FAR-FIELD: wide-scale release, multiple sites

Complete

Complete

TRANSPORT OPTIONS============ Section

EXPOSURE PATHWAY OPTIONS $=====$ Section

$T$ Air Transport

1

Surface Water Transport

$F$ Finite plume, external 5

F Biotic Transport (near-field)

2

T Infinite plume, external

Ground, external

$F$ Waste Form Degradation (near) 3,4

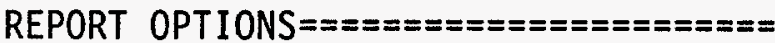

F Recreation, external

T Inhalation uptake

$F$ Drinking water ingestion

$F$ Aquatic foods ingestion

F Terrestrial foods ingestion

$F$ Animal product ingestion

$F$ Inadvertent soil ingestion

5 5,6

7,8

7,8

$T$ Report by radionuclide

$F$ Report by exposure pathway

$F$ Debug report on screen

\section{INVENTORY \#\#\#\#\#\#\#\#\#\#\#\#\#\#\#\#\#\#\#\#\#\#\#\#\#\#\#\#\#\#\#\#\#\#\#\#\#\#\#\#\#\#\#\#\#\#\#\#\#\#\#\#\#\#\#\#\#\#\#\#\#\#\#\#\#\#\#}

4 Inventory input activity units: ( $1-\mathrm{pCi} \quad 2-\mathrm{uCi} \quad 3-\mathrm{mCi} \quad 4-\mathrm{Ci} \quad 5-\mathrm{Bq})$

0 Surface soil source units (1- $\left.\mathrm{m}^{2} 2-\mathrm{m} 3 \quad 3-\mathrm{kg}\right)$

Equilibrium question goes here.

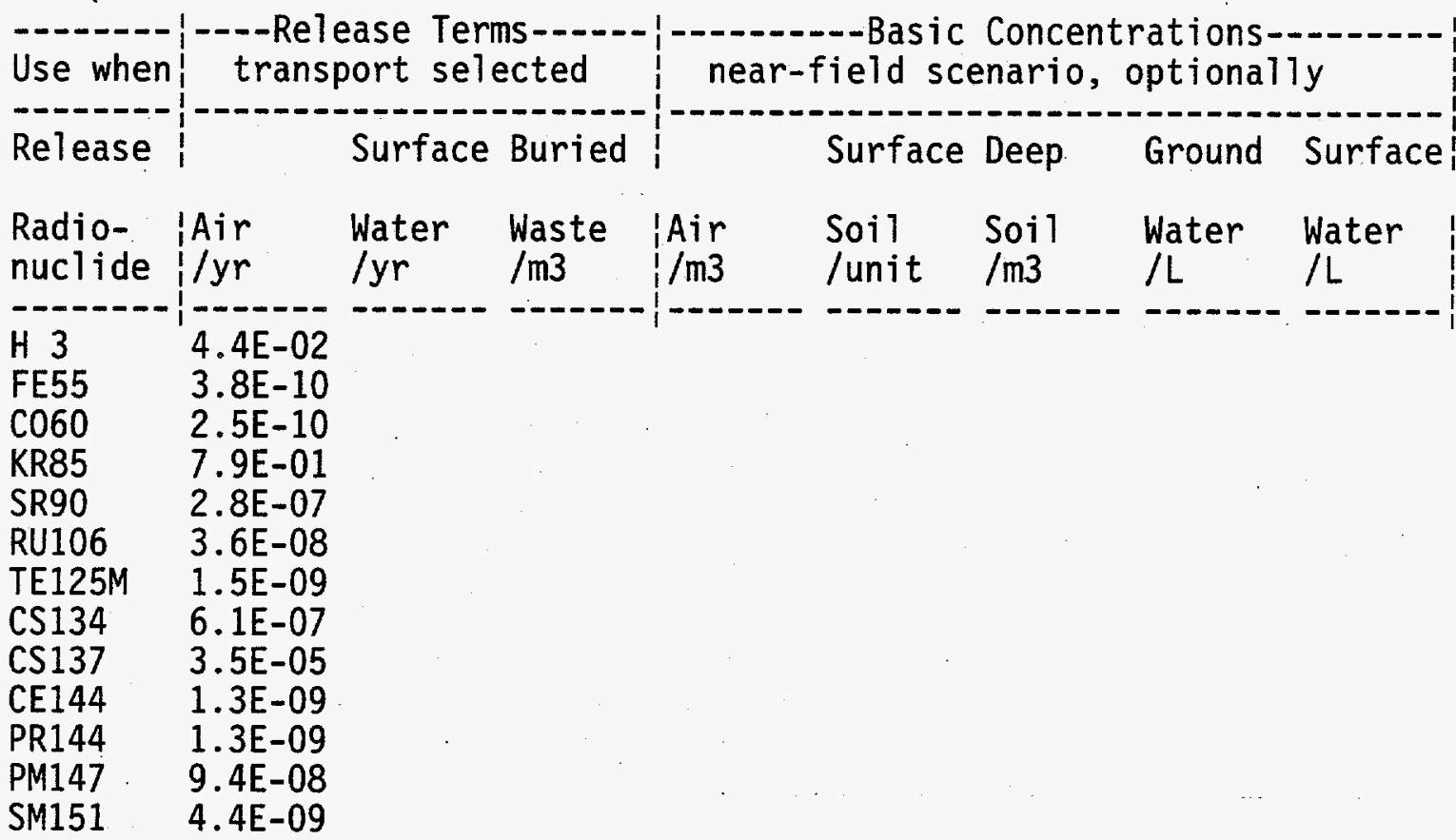




$\begin{array}{ll}\text { EU154 } & 4.2 \mathrm{E}-09 \\ \text { U 235 } & 7.4 \mathrm{E}-13 \\ \text { U 238 } & 1.6 \mathrm{E}-11 \\ \text { NP237 } & 1.4 \mathrm{E}-12 \\ \text { PU238 } & 2.4 \mathrm{E}-09 \\ \text { PU239 } & 5.5 \mathrm{E}-09 \\ \text { PU240 } & 2.9 \mathrm{E}-09 \\ \text { PU241 } & 2.2 \mathrm{E}-07 \\ \text { AM241 } & 4.6 \mathrm{E}-09 \\ \text { CM244 } & 2.3 \mathrm{E}-10\end{array}$

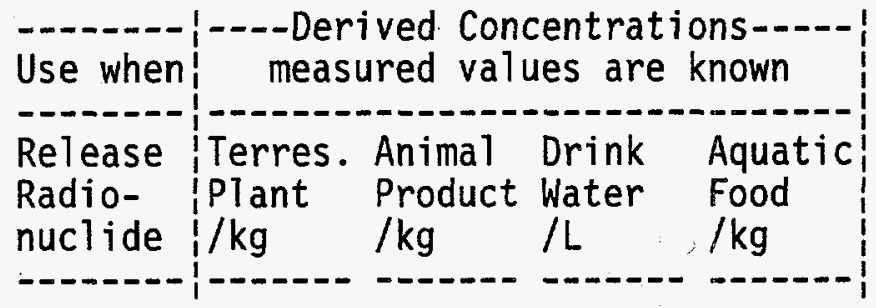

TIME \#\#\#\#\#\#\#\#\#\#\#\#\#\#\#\#\#\#\#\#\#\#\#\#\#\#\#\#\#\#\#\#\#\#\#\#\#\#\#\#\#\#\#\#\#\#\#\#\#\#\#\#\#\#\#\#\#\#\#\#\#\#\#\#\#\#\#\#\#\#

1 Intake ends after $(y r)$

50 Dose calc. ends after (yr)

0 Release ends after (yr)

0 No. of years of air deposition prior to the intake period

0 No. of years of irrigation water deposition prior to the intake period

FAR-FIELD SCENARIOS (IF POPULATION DOSE) \#\#\#\#\#\#\#\#\#\#\#\#\#\#\#\#\#\#\#\#\#\#\#\#\#\#\#\#\#\#\#\#

1 Definition option: 1-Use population grid in file POP.IN

0 2-Use total entered on this line

\section{NEAR-FIELD SCENARIOS \#\#\#\#\#\#\#\#\#\#\#\#\#\#\#\#\#\#\#\#\#\#\#\#\#\#\#\#\#\#\#\#\#\#\#\#\#\#\#\#\#\#\#\#\#\#\#\#\#\#\#\#\#\#}

Prior to the beginning of the intake period: (yr)

$0 \quad$ When was the inventory disposed? (Package degradation starts)

$0 \quad$ When was LOIC? (Biotic transport starts).

$0 \quad$ Fraction of roots in upper soil (top $15 \mathrm{~cm}$ )

$0 \quad$ Fraction of roots in deep soil

0 Manual redistribution: deep soil/surface soil dilution factor

$0 \quad$ Source area for external dose modification factor (m2)

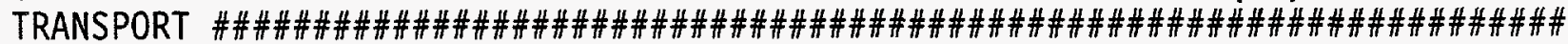

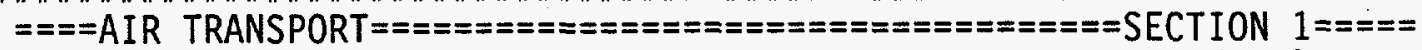

0 -Calculate PM

Option: 1-Use chi/Q or PM value IF 2-Select MI dist \& dir 0 3-Specify MI dist \& dir 0

Chi/Q or PM value

16 MI sector index (1=S)

$0 \quad M I$ distance from release point (m) 0

$T \quad$ Use jf data, (T/F) else chi/Q gridio
Release type $(0-3)$

Stack release $(T / F)$

Stack height (m)

Stack flow (m3/sec)

Stack radius (m)

Effluent temp. (c)

Building x-section (m2)

Building height $(\mathrm{m})$ 


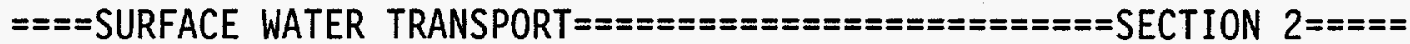
Mixing ratio model: 0-use value, 1-river, 2-lake Mixing ratio, dimensionless

Average river flow rate for: MIXFLG=0 (m3/s), MIXFLG $=1,2(\mathrm{~m} / \mathrm{s})$, Transit time to irrigation withdrawal location (hr)

If mixing ratio model $>0$ :

Rate of effluent discharge to receiving water body $(\mathrm{m} 3 / \mathrm{s})$

Longshore distance from release point to usage location (m)

offshore distance to the water intake $(\mathrm{m})$

Average water depth in surface water body $(\mathrm{m})$

Average river width (m), MIXFLG $=1$ only

Depth of effluent discharge point to surface water $(m)$, lake only

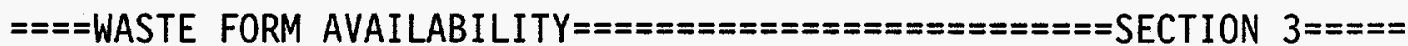
Waste form/package half life, (yr)

Waste thickness, (m)

Depth of soil overburden; m

$====$ BIOTIC TRANSPORT OF BURIED SOURCE $===============$ SECTION $4=====$ Consider during inventory decay/buildup period (T/F)?

Consider during intake period (T/F)? | 1-Arid non agricultural

Pre-Intake site condition............ 2-Humid non agricultural 3-Agricultural

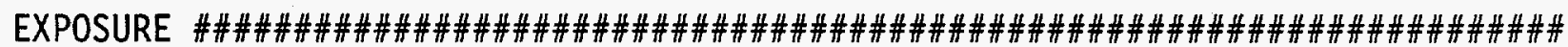

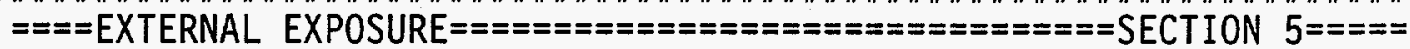

Exposure time:

Plume (hr)

Residential irrigation:

Soil contamination (hr)

$T$ Consider: (T/F)

Swimming (hr)

Source: 1-ground water

Boating (hr)

2-surface water

Shoreline activities (hr) 0 Duration (mo/yr)

Shoreline type: (1-river, 2-lake, 3-ocean, 4-tidal basin)

Transit time for release to reach aquatic recreation ( $h r$ )

1.0

8766.0

0

0

Average fraction of time submersed in acute cloud ( $\mathrm{hr} /$ person $\mathrm{hr}$ )

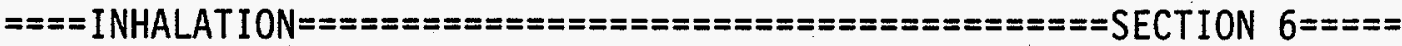
Hours of exposure to contamination per year

0 -No resus- 1-Use Mass Loading pension Mass loading factor $(\mathrm{g} / \mathrm{m} 3)$

2-Use Anspaugh model

Top soil available $(\mathrm{cm})$

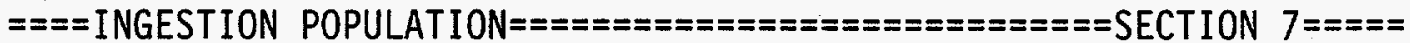

Atmospheric production definition (select option):

0 -Use food-weighted chi/Q, (food-sec/m3), enter value on this line 1-Use population-weighted chi/Q

2-Use uniform production

3-Use chi/Q and production grids (PRODUCTION will be overridden)

Population ingesting aquatic foods, 0 defaults to total (person)

Population ingesting drinking water, 0 defaults to total (person)

Consider dose from food exported out of region (default=F) 
Note below: $S^{*}$ or Source: 0-none, 1-ground water, 2-surface water 3-Derived concentration entered above $====$ AQUATIC FOODS / DRINKING WATER INGESTION $=========$ SECTION $8====$ Salt water? (default is fresh)

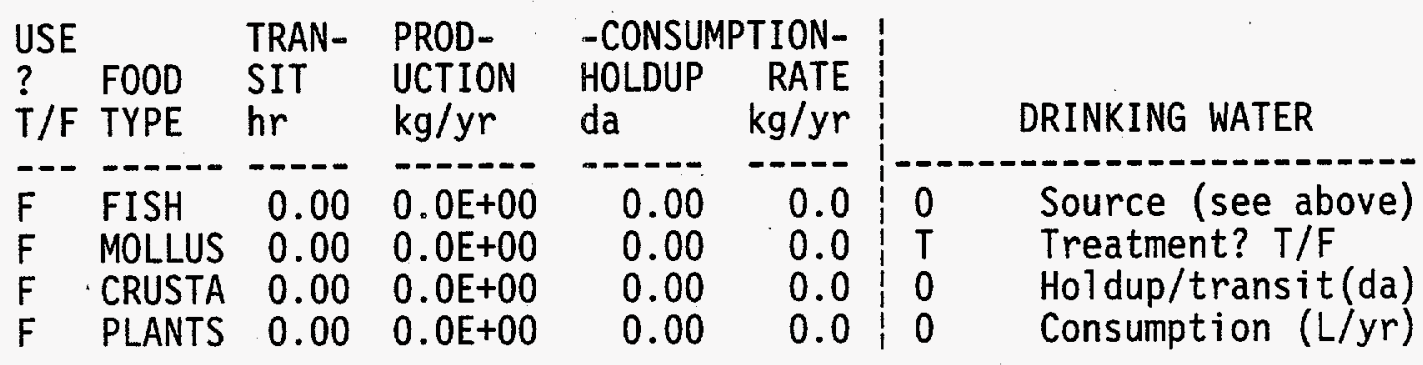

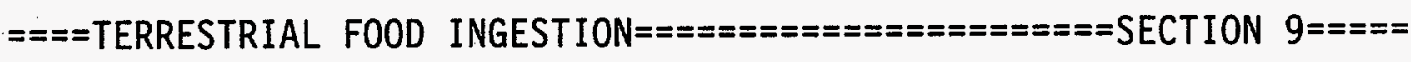

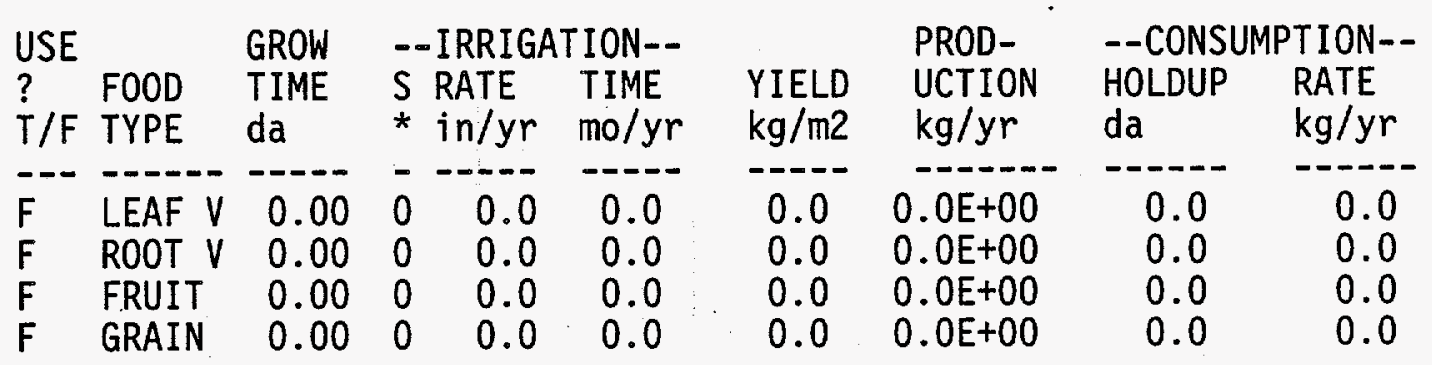




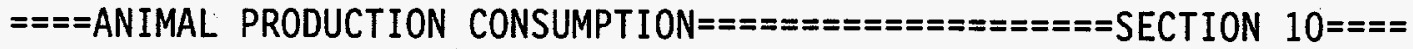

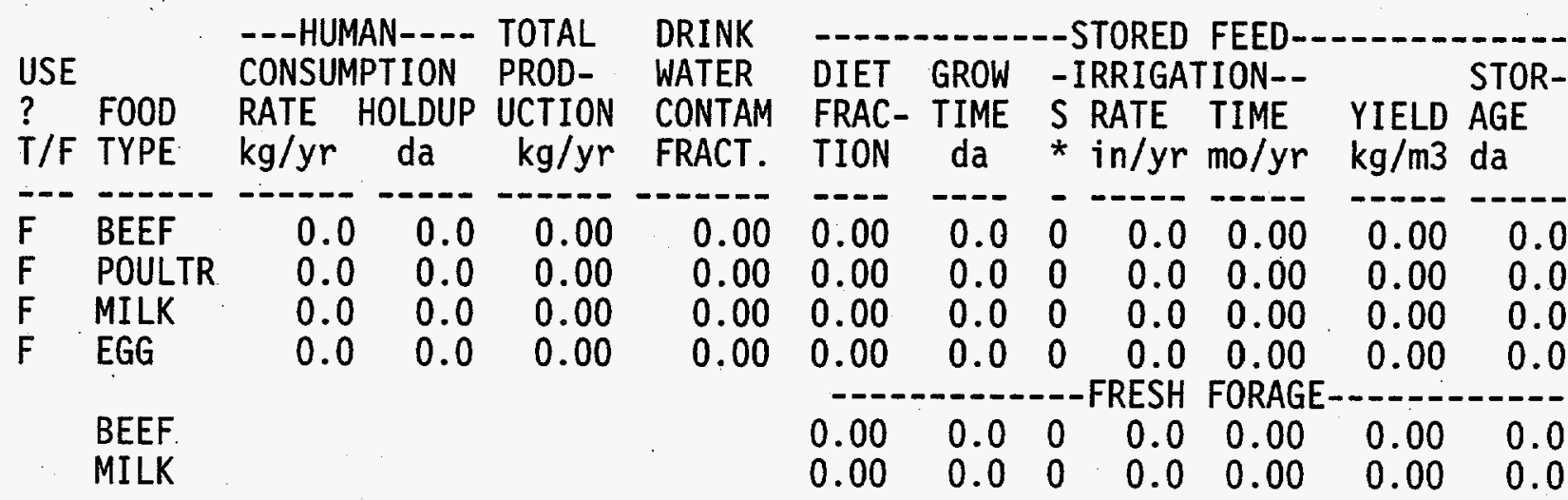

\#\#\#\#\#\#\#\#\#\#\#\#\#\#\#\#\#\#\#\#\#\#\#\#\#\#\#\#\#\#\#\#\#\#\#\#\#\#\#\#\#\#\#\#\#\#\#\#\#\#\#\#\#\#\#\#\#\#\#\#\#\#\#\#\#\#\#\#\#\#\#\#\#\#\#\# 
\#\#\#\#\#\#\#\#\#\#\#\#\#\#\#\#\#\#\#\#\#\#\# Program GENII Input File \#\#\#\#\#\#\#\#\#\#\#8 Jul 88 \#\#\#\# Title: N-Fuel - Population Dose; Ingestion Pathway

$\backslash$ GENII Infuel-8. in

Created on $08-10-1994$ at $10: 37$

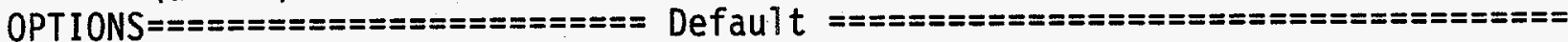

$F \quad$ Near-field scenario?

T Population dose?

T Acute release?

(Far-field)

(Individual)

NEAR-FIELD: narrowly-focused release, single site Average Individual data set used

FAR-FIELD: wide-scale release, (Chronic) multiple sites

Complete

TRANSPORT OPTIONS============ Section

Complete

$T$ Air Transport

F Surface Water Transport

1

Biotic Transport (near-field) 3,4

$F$ Waste Form Degradation (near) 3,4

REPORT OPTIONS============="=="=="=="==

$T$ Report AEDE only

$T$ Report by radionuclide

F Report by exposure pathway

$F$ Debug report on screen

EXPOSURE PATHWAY OPTIONS $=====$ Section

$F$ Finite plume, external 5

F Infinite plume, external 5

$F$ Ground, external

F Recreation, external

5

$F$ Inhalation uptake

5,6

T Drinking water ingestion 7,8

T Aquatic foods ingestion 7,8

T Terrestrial foods ingestion 7,9

T Animal product ingestion 7,10

F Inadvertent soil ingestion

INVENTORY $\# \# \# \# \# \# \# \# \# \# \# \# \# \# \# \# \# \# \# \# \# \# \# \# \# \# \# \# \# \# \# \# \# \# \# \# \# \# \# \# \# \# \# \# \# \# \# \# \# \# \# \# \# \# \# \# \# \# \# \# \# \#$

4 Inventory input activity units: ( $1-\mathrm{pCi} \quad 2-\mathrm{uCi} \quad 3-\mathrm{mCi} \quad 4-\mathrm{Ci} \quad 5-\mathrm{Bq})$

0 Surface soil source units (1- m2 2- $\mathrm{m} 33-\mathrm{kg}$ )

Equilibrium question goes here

\begin{tabular}{|c|c|c|c|c|c|c|c|c|}
\hline Use when & transf & port sel & ected & & eld sc & enario & option & \\
\hline lease & & Surface & Buried & & Surface & Deep & Ground & Surface \\
\hline $\begin{array}{l}\text { Radio- } \\
\text { nuclide }\end{array}$ & $\begin{array}{l}A i r \\
/ y r\end{array}$ & $\begin{array}{l}\text { Water } \\
\text { /yr }\end{array}$ & $\begin{array}{l}\text { Waste } \\
\text { /m3 }\end{array}$ & Air & $\begin{array}{l}\text { Soil } \\
\text { /unit }\end{array}$ & $\begin{array}{l}\text { Soi } 1 \\
\text { /m3 }\end{array}$ & $\begin{array}{l}\text { Water } \\
/ L\end{array}$ & $\begin{array}{l}\text { Water } \\
/ L\end{array}$ \\
\hline $\begin{array}{l}\text { H } 3 \\
\text { FE55 } \\
\text { CO60 } \\
\text { KR85 } \\
\text { SR90 } \\
\text { RU106 } \\
\text { TE125M } \\
\text { CS134 } \\
\text { CS137 } \\
\text { CE144 } \\
\text { PR144 } \\
\text { PM147 } \\
\text { SM151 }\end{array}$ & $\begin{array}{l}4.4 \mathrm{E}-02 \\
3.8 \mathrm{E}-10 \\
2.5 \mathrm{E}-10 \\
7.9 \mathrm{E}-01 \\
2.8 \mathrm{E}-07 \\
3.6 \mathrm{E}-08 \\
1.5 \mathrm{E}-09 \\
6.1 \mathrm{E}-07 \\
3.5 \mathrm{E}-05 \\
1.3 \mathrm{E}-09 \\
1.3 \mathrm{E}-09 \\
9.4 \mathrm{E}-08 \\
4.4 \mathrm{E}-09\end{array}$ & & & & & & & \\
\hline
\end{tabular}




$\begin{array}{ll}\text { EU154 } & 4.2 \mathrm{E}-09 \\ \text { U } 235 & 7.4 \mathrm{E}-13 \\ \text { U 238 } & 1.6 \mathrm{E}-11 \\ \text { NP237 } & 1.4 \mathrm{E}-12 \\ \text { PU238 } & 2.4 \mathrm{E}-09 \\ \text { PU239 } & 5.5 \mathrm{E}-09 \\ \text { PU240 } & 2.9 \mathrm{E}-09 \\ \text { PU241 } & 2.2 \mathrm{E}-07 \\ \text { AM241 } & 4.6 \mathrm{E}-09 \\ \text { CM244 } & 2.3 \mathrm{E}-10\end{array}$

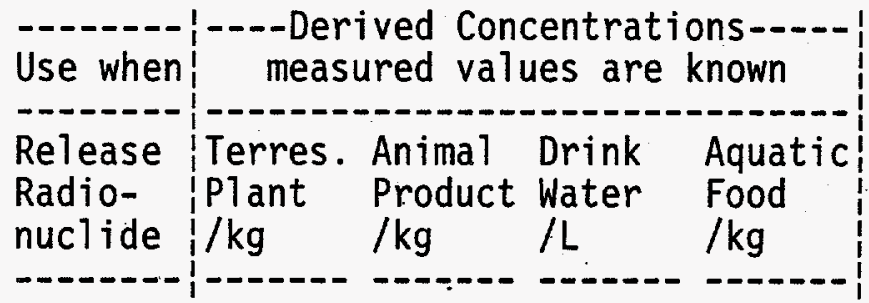

TIME \#\#\#\#\#\#\#\#\#\#\#\#\#\#\#\#\#\#\#\#\#\#\#\#\#\#\#\#\#\#\#\#\#\#\#\#\#\#\#\#\#\#\#\#\#\#\#\#\#\#\#\#\#\#\#\#\#\#\#\#\#\#\#\#\#\#\#\#\#\#\#\#\#

1 Intake ends after (yr)

50 Dose calc. ends after (yr)

0 . Release ends after (yr)

0 No. of years of air deposition prior to the intake period

0 No. of years of irrigation water deposition prior to the intake period

FAR-FIELD SCENARIOS (IF POPULATION DOSE) \#\#\#\#\#\#\#\#\#\#\#\#\#\#\#\#\#\#\#\#\#\#\#\#\#\#\#\#\#\#\#\#\#\#\#\#

1 Definition option: 1-Use population grid in file POP. IN

0

2-Use total entered on this line

NEAR-FIELD SCENARIOS \#\#\#\#\#\#\#\#\#\#\#\#\#\#\#\#\#\#\#\#\#\#\#\#\#\#\#\#\#\#\#\#\#\#\#\#\#\#\#\#\#\#\#\#\#\#\#\#\#\#\#\#\#\#

Prior to the beginning of the intake period: (yr)

$0 \quad$ When was the inventory disposed? (Package degradation starts)

$0 \quad$ When was LOIC? (Biotic transport starts)

0 Fraction of roots in upper soi1 (top $15 \mathrm{~cm}$ )

$0 \quad$ Fraction of roots in deep soil

0 Manual redistribution: deep soil/surface soil dilution factor

$0 \quad$ Source area for external dose modification factor (m2)

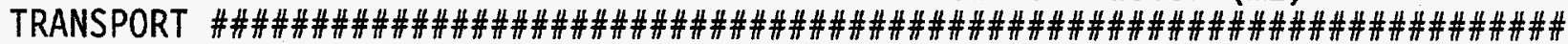

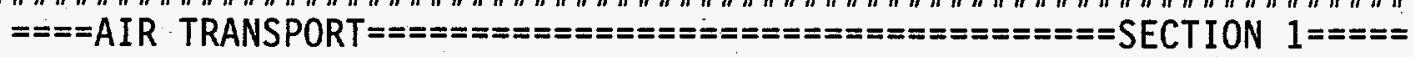

0 -Calculate PM

3 Option: 1-Use chi/Q or PM value 2-Select MI dist \& dir 0 3-Specify MI dist \& dir 0

$0 \quad$ Chi/Q or PM value

16 MI sector index (1=S)

10 Release type $(0-3)$

Stack release (T/F)

Stack height $(\mathrm{m})$

Stack flow (m3/sec)

Stack radius (m)

Effluent temp. (C)

$0 \quad$ MI distance from release point $(\mathrm{m})$

Building $x$-section (m2) Use jf data, (T/F) else chi/Q gridio

Building height $(\mathrm{m})$ 


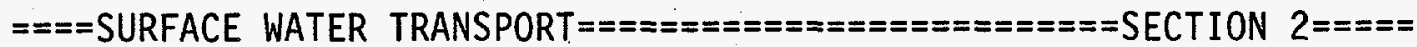
Mixing ratio model: 0 -use value, 1-river, 2 -lake Mixing ratio, dimensionless

Average river flow rate for: MIXFLG=0 (m3/s), MIXFLG=1,2 (m/s), Transit time to irrigation withdrawal location (hr)

If mixing ratio model $>0$ :

Rate of effluent discharge to receiving water body $(\mathrm{m} 3 / \mathrm{s})$ Longshore distance from release point to usage location (m) offshore distance to the water intake $(\mathrm{m})$ Average water depth in surface water body $(\mathrm{m})$ Average river width (m), MIXFLG=1 only Depth of effluent discharge point to surface water (m), lake only

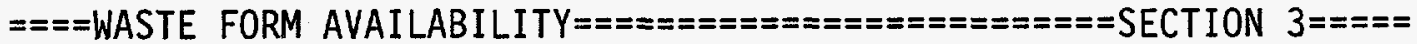
Waste form/package half life, (yr)

Waste thickness, (m)

Depth of soil overburden, $m$

$====$ BIOTIC TRANSPORT OF BURIED SOURCE $===============$ SECTION $4=====$ Consider during inventory decay/buildup period (T/F)?

Consider during intake period (T/F)? I-Arid non agricultural

Pre-Intake site condition............. 2-Humid non agricultural 3-Agricul tural

EXPOSURE \#\#\#\#\#\#\#\#\#\#\#\#\#\#\#\#\#\#\#\#\#\#\#\#\#\#\#\#\#\#\#\#\#\#\#\#\#\#\#\#\#\#\#\#\#\#\#\#\#\#\#\#\#\#\#\#\#\#\#\#\#\#\#\#\#\#\#

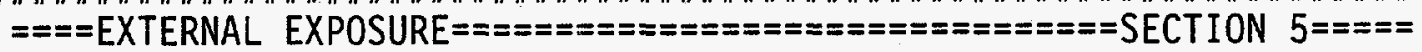
Exposure time:

0

2920.0

0

0

0

0

0

1.0

8766.0

0

0

1

0

\section{0}

0.0

$\mathrm{F}$
Plume (hr)

Soil contamination (hr)

Swimming ( $h r)$

Boating (hr)

Shoreline activities ( $h r$ )
Residential irrigation:

$T$ Consider: (T/F)

0 Source: 1-ground water

2-surface water

0

0
Application rate (in/yr)

Duration (mo/yr)

Shoreline type: (1-river, 2-lake, 3-ocean, 4-tidal basin)

Transit time for release to reach aquatic recreation (hr)

Average fraction of time submersed in acute cloud ( $\mathrm{hr} / \mathrm{person} \mathrm{hr}$ )

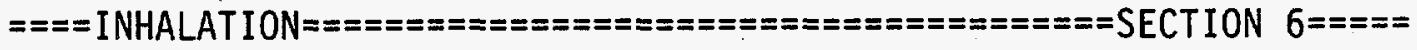
Hours of exposure to contamination per year

0 -No resus- 1-Use Mass Loading pension

Mass loading factor $(\mathrm{g} / \mathrm{m} 3)$

2-Use Anspaugh model

Top soil available $(\mathrm{cm})$

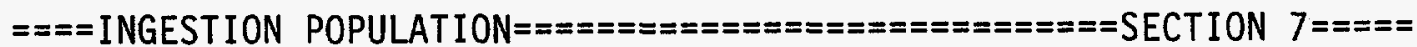
Atmospheric production definition (select option):

0 -Use food-weighted chi/Q, (food-sec/m3), enter value on this line 1 -Use population-weighted chi/Q

2-Use uniform production

3-Use chi/Q and production grids (PRODUCTION will be overridden) Population ingesting aquatic foods, 0 defaults to total (person) Population ingesting drinking water, 0 defaults to total (person) Consider dose from food exported out of region (default=F) 
Note below: $S^{*}$ or Source: 0-none, 1-ground water, 2-surface water 3-Derived concentration entered above $====$ AQUATIC FOODS / DRINKING WATER INGESTION $=========$ SECTION $8====$

Salt water?. (default is fresh)

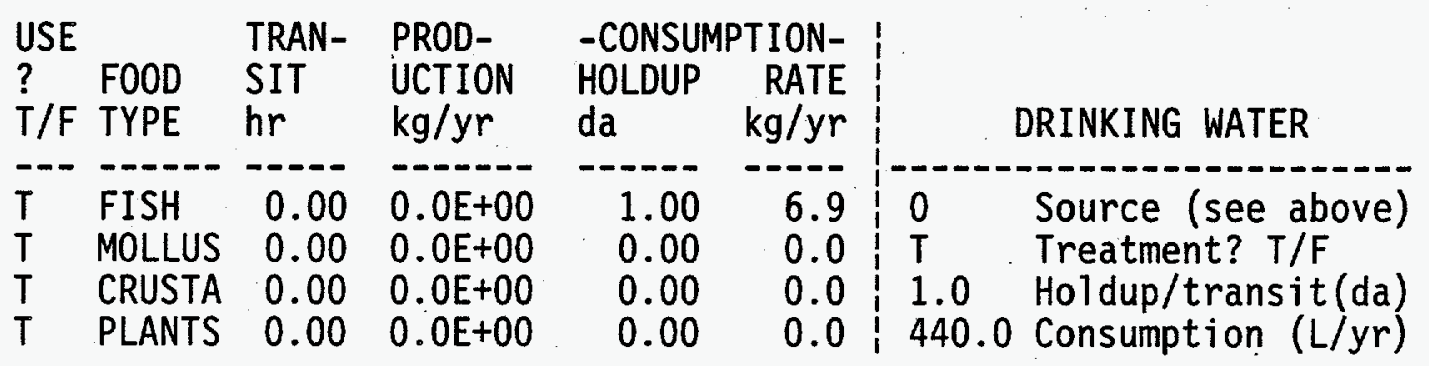

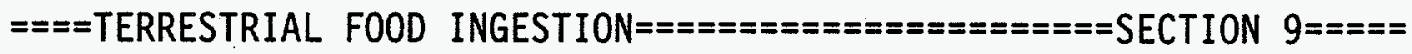

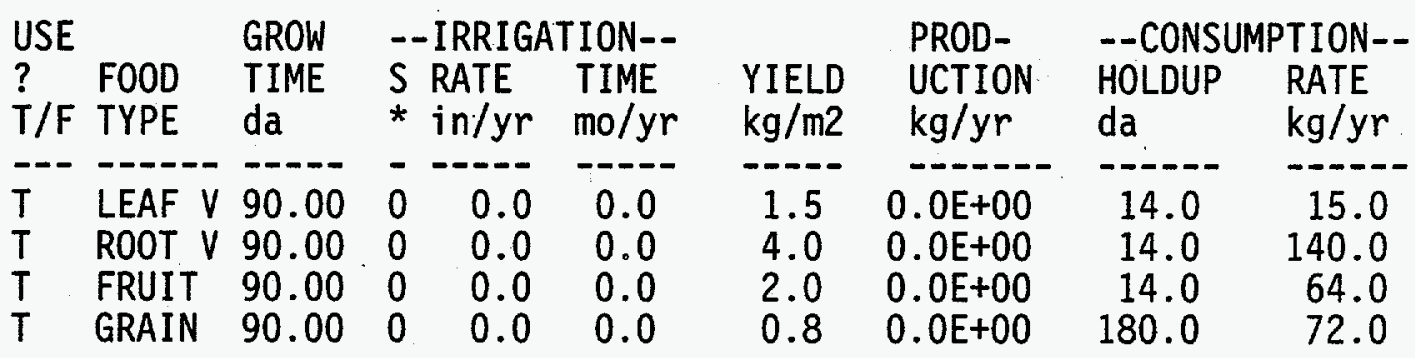


$===$ ANIMAL PRODUCTION CONSUMPTION $===================$ SECTION $10====$

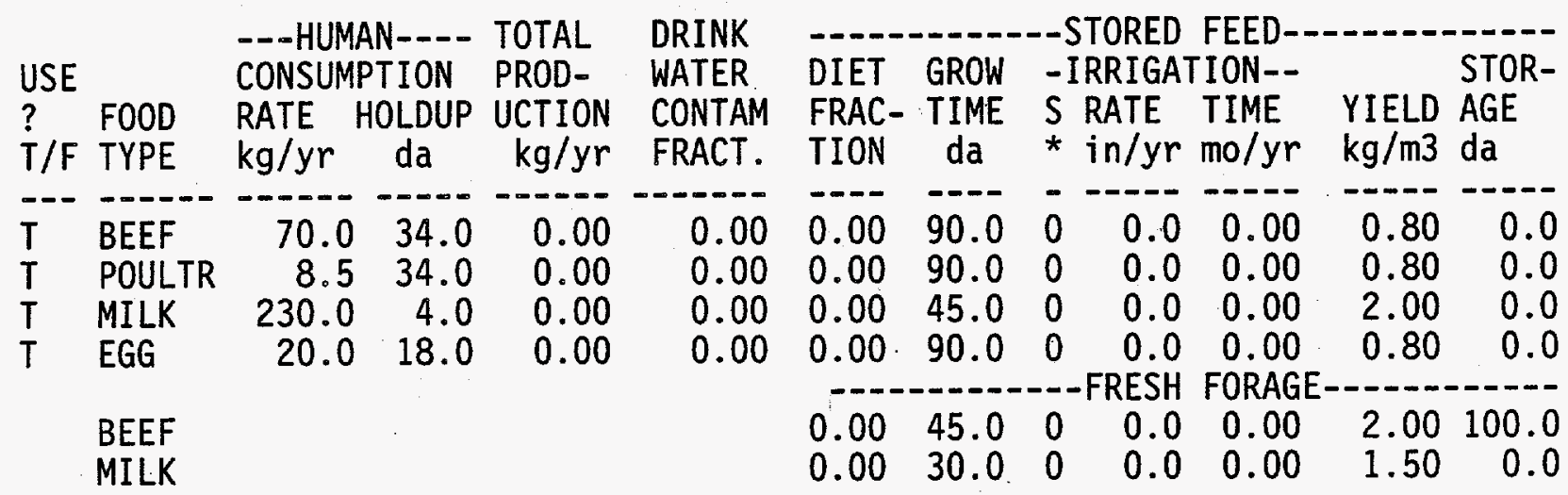

\#\#\#\#\#\#\#\#\#\#\#\#\#\#\#\#\#\#\#\#\#\#\#\#\#\#\#\#\#\#\#\#\#\#\#\#\#\#\#\#\#\#\#\#\#\#\#\#\#\#\#\#\#\#\#\#\#\#\#\#\#\#\#\#\#\#\#\#\#\# 
PNL-10249

UC-630

\section{DISTRIBUTION}

No. of

Copies

OFFSITE

2 DOE/Office of Scientific and Technical Information

\section{ONSITE}

2 DOE Richland Operations office

S. S. Clark, R3-81

P. F. Dunigan, A5-15

4 West inghouse Hanford Company

D. W. Bergmann, R3-86

J. R. Green, G2-02

M. T. Jansky, H6-26

E. F. Votaw, G2-02
No. of

Copies

25 Pacific Northwest Laboratory

J. Abrefrah, P7-14

P. M. Daling (10), K8-07

E. A. Flores, K8-12

M. S. Madden, K8-07

S. C. Marschman, P7-18

I. C. Nelson, K3-54

P. J. Pelto, K7-97

M. R. Peterson, K8-23

K. Rhoads, K3-54

D. B. Shipler, K9-13

Publishing Coordination

Technical Report Files (5) 